\title{
Performance Of Financial Institutions In Five Sub-Saharan African Countries
}

\author{
Husein Mohamed Irbad \\ Research Scholar, \\ Annamalai University \\ +252615840544 \\ Cirbad10@yahoo.com \\ Dr. M. G. Jayaprakash \\ Assistant Professor, Annamalai University, \\ Department of Business Administration, India
}

\begin{abstract}
The purpose of this study is to investigate the performance of financial institutions in five Sub-Saharan African countries: Kenya, Nigeria, Namibia, Rwanda and Senegal. The investigation is based on four proxies towards performance namely: financial access, financial depth, financial efficiency and financial stability. The overall proxies are composed of thirty variables. There are four objectives in the study; the first objective has examined access and information of financial services in financial institutions of Sub-Saharan African countries. The second objective investigated and measured depth of financial institutions. The third objective evaluated efficiency of financial institutions in Sub-Sahara Africa. The last objective was intended to measure the stability of financial institutions in Africa. We created a development of financial performance model describing the proxies and variables in this study. The main analysis of the study is Mean calculation and regression analysis by using weighted Least Squares multiple regression analysis (WLS). This study investigated secondary data. The data was analyzed by using Excel software and Statistical Package for Social Sciences (SPSS) in descriptive statistics. The result of all target countries except Nigeria is significant in financial access. Result also showed significance in financial depth of all five target countries. The financial institutions of all five target countries are inefficient. Also the result of financial stability in financial institutions of target countries showed insignificance except Rwanda.
\end{abstract}

Keywords: financial access; financial depth; financial efficiency; financial stability; SubSahara Africa

\section{History of African Financial Institutions}

\section{INTRODUCTION}

Africa passed through four centuries of slavery including the so called sixty years of colonial rule. During those tough times, Africa under cultural variety managed to develop diverse and fluid forms of financial institutions which successfully introduced currency transactions such as valuation and conversion, storage and security, forecasting and trust (amana), and of course profit. African financial institutions dating back to the end of fifteen's century worked hard towards commercialization of Africa's economy and integration of commodity trades. The history of African financial institutions has been related to constant development and innovation of formal sectors in both state-owned and private institutions. During the precolonial era, those African financial institutions developed statistical techniques to calculate risk and introduced terms of time-frames that can allow fixation of financial transactions by law. They built regional market systems and they had their own indigenous currencies including cowry currency which has been imported in the era of slave trade, though it is under 
question whether the cowry currency have evolutionary concept to Africa's monetary history. In $19^{\text {th }}$ century, in the formal sector of money management, labor-pawning has been related to Africa's economic growth but this needs a proof of relevance to credit and debt. On the other hand, history noted that there have been several phases of monetary circulation in which some of them were known as conditions of loan repayment which were related to the labor-pawning. This kind of monetary circulation was clearer than instruments of credit advances and circumstances of wealth. Historians believe that African credit structure is much understandable than analyzing loan repayment. The commercial civilization of Africa had been through long distance trade which made possible underwriting their state development, creating market engagement and money. In Africa's history of financial institutions, sometimes money management happened out of state control due to conditions of trade networks and behaviors of local production which depended on different modes of valuation and sanctioning. The researcher believes this out of control money situation is no different from today's untaxed financial transactions. During the pre-colonial era, Dahomey (Republic of Benin) successfully controlled money management and the supply of currencies. The Mourides of Senegal developed a kind of institutional framework which aimed towards large scale of transnational financial structure composed of formal legal organizations and religious authority relations. The researcher wants to remind the readers of this report of the context of African financial institutions in historical perspective that the African work of financial services is based on the Islamic law which is a common system and practice determining cohering ideas, selecting applications under different material conditions, and the underlying principles of guidelines and legal provisions relative to the institutional means when it comes to mediating views from Islamic different doctrines. Also, there were other cultures that had clear history on the African financial institutions such as Yoruba conceptualization which was deeply related to the economic relations of the African continent. One good Yoruba business example is the case of pawning relative to the productive capacity of the lender which gives customers a chance to access financial institutions. Up to the 1920s, to practicing the business context of Yoruba conceptualization, African people used to pawn themselves or their relatives such as siblings to get a loan from a lender. The pawned person used to do a labor and the lender used to get the output of the labor as an interest until the loan is fully repaid. Pawning was different from slavery. During the time, there were legal practices for making the contract of pawning with rights and obligations that defined its limits and completion. The major benefits of pawning were mechanism of access to capital in the perspective of customers (loan seekers) and investment of surplus with security and return in the perspective of lenders (creditors). Both Islamic and Yoruba cases contributed culture and commercial fabric to the history of African financial institutions but in respect of economic concepts and ideas, the Islamic tradition has a legal discourse while Yoruba does not have. When it comes to credit and debt management, time always was a fluid concept but at the beginning of the $19^{\text {th }}$ century, the western colonial rule contributed per their understanding of time as a fixed measure and this concept of time measurement was incorporated into the African financial institutions. This is how cooperative membership dues and loan repayments were transformed per according of fixed schedules which is why we are having today some institutions which are dealing transformation of money management with the possibility of default. Also for the first time in the history of African financial institutions, loans, repayments and contributions were adjusted to the rural income under the French rule colony (Stiansen \& Guyer, 1999).

\section{Credit and Currency of West Coast in Pre-colonial Era}

It is doubtless that cowries were a circulating currency in West Africa during $17^{\text {th }}$ century. Cowry is a sea shell imported from Indian Ocean to the coast of West Africa by traders. There are two different beliefs about how cowries were first introduced into the West coast of Africa 
known as coast of slave: (1) historians believe that traders from the Islamic world first introduced cowries into West Africa through Sahara before the beginning of European maritime trade. (2) The locals believe European traders brought cowry Sea shells into the coast of West Africa. There are two facts which may decide who brought cowries into Sub-Sahara Africa. Fact one; Muslim trade to Sub-Sahara Africa is dating back to the year of 1704 and during that time Muslims were purchasing cowries but not importing. Fact two; commercialization of African economy was involved by the Europeans in the $16^{\text {th }}$ century. The researcher presents the following interesting analogy to support the decision about who brought Cowry Sea shells into Africa first? "The 17th century started January $1^{\text {st }} 1601$ and lasted to December $31^{\text {st }} 1700$ in the Gregorian calendar". This proves that the involvement of Muslim traders to Sub-Sahara Africa is the beginning of the $18^{\text {th }}$ century or the year of 1704 . "The $16^{\text {th }}$ century started with the Julian year of 1501and ended with either the Julian or the Gregorian year of 1600. In the $16^{\text {th }}$ century, there is a lapse of 10 days in October of 1582 during the Gregorian calendar". There are many years in between during the commercialization of African economy by the European traders and Muslim trade in Sub-Sahara Africa. This may prove that the European traders brought cowries into Africa first. The analogy mentioned above is the insight of the researcher. Who ever brought those Sea shells into Sub-Sahara Africa: Muslims or Europeans? The cowry currency promoted credit expansion during the time of pre-colonial era. Unfortunately, cowry currencies (Sea shells) were used as instrument for buying slaves on credit. This commercial credit of slave trade was an innovation of credit extension to each other; Europeans and Africans. The origin of credit extension was from the African side. It was in the middle of $16^{\text {th }}$ century, the year of 1553 when the King of Dahomey (Benin) extended a credit to English traders until their next voyage. Transactions of commercial goods on credit were Palm Oil, Tobacco, Pepper, Clothes and Slaves. Insolvency of debt and enforcement of debt repayment were normally handled by royal courts of Allada and Whydah in Dahomey. "Panyarring" was a debt enforcement law which allowed of seizing and enslaving insolvent debtors and their family members. Later the act of "Panyarring" was abolished or suppressed under Dahomean rule. In 1676, there was an indigenous system of recording financial transactions. In Dahomey, financial institutions used Knotted strings to record commercial transactions in which each knotted string represented a bag of 20,000 cowries. Also there were other mechanical devices such as wooden tallies and pieces of cloth marked with indigo used to record commercial transactions. Later the European traders introduced the modern bills of exchange, the "Promissory note" into the cost of slave for recording credit transactions, although written documents used to settle liabilities (Promissory notes) were common in West Africa during $10^{\text {th }}$ century by the introduction of the Islamic world, yet the promissory note innovated recording commercial and financial transactions in Dahomey. During pre-colonial era, the cowries-currency was used as store of wealth. In 19 ${ }^{\text {th }}$ century, in Dahomey, there was a royal treasury called "cowries house" in which cowries-currency was centrally issued and received in taxation but there is no proof that the royal treasury operated as a central bank. Also in Dahomey, there were individuals who kept large stores of cowries-currency on their own in protected buildings inside their compounds. A few people recently argued that those cowries-store-houses worked as banks and their owners as bankers during pre-colonial era. But there is an undisputed proof that the owners of those storehouses accepted cowriescurrency as a deposit from the general public who preferred the storehouses for security reasons where the storehouse owners served the deposits of cowries-currency as a loan to others. The researcher is presenting the following analogy to support concept of existing banks in pre-colonial era in Yoruba country. There is no way the cowries-currency deposits is different from how the modern commercial banks mobilize their deposits to investment to generate financial services after these banks made possible the negotiations between depositors and loan seekers. The European missionaries in pre-colonial era to Yoruba land, in east Dahomey also proved that there was money saving clubs called tontines locally known as 
esusu. Late in $19^{\text {th }}$ century, the cowries-currency lost its value as storing and lending of money in large stocks because of inflation (Stiansen \& Guyer, 1999).

\section{Currency Zones, Currency Transformation and Credit Practices}

During $18^{\text {th }}$ and first half of $19^{\text {th }}$ century, there were three currency zones namely: (1) the monetized metal zone in which its centre was in the Islamic Mediterranean to the north, (2) the cowry zone stretched to the east and south, and (3) the zone of mixed commodity money that dealt with silver coin, iron, cloth, and glassware which located the Atlantic coast to the west. In these currency zones, there were markets where merchants and traders from Europe, western Sahel in North Africa region, and black Africans from the south meet and carry out their commercial transactions. The operation activities in the monetary environment were extremely complicated due to two reasons: (1) currency frontiers in which credit was extended to economic actors belonged to different cultural communities, and (2) some currencies may become less acceptable by other cultures because the currency is predominated in one zone or the currency is too expensive due to cost of transportation. Also there were other barriers such as risk of enslaving traders by communities of opposite cultures and other risk factors such as malaria and fever which were common in Sub-Sahelian Africa particularly during the rainy season. All above mentioned risks and risk factors limited the exposure of trade in the region that connected three different groups of merchants. The three currency zones did not make progress beyond their frontiers over time. Why? What happened? The monetized metal zone couldn't introduce its currency to the Western Sahel and the Savannah of West Africa for two possible reasons: (1) concentration of wealth characterized by the Mediterranean region encouraged the outflow of gold from Sub-Sahara Africa to compensate their imports in which they favored such kind of trade as a local utility. (2) During this time there was a situation of political violence resulted by the last great West African savannah Empire (Songhai) which collapsed in 1591. The fragmented successors favored to the use of commodity money because of their environment which was less economic productive and decided to neglect the high value monetized metal currency. As the researcher previously mentioned, the cowry-currency was involved in the "slave trade." Slaves were used as goods on demand in exchange but not between the currency zones. Goods such as slaves and gold used to increase their value with distance from the point of acquisition. So, this kind of trade between the two currency zones: the Western Sahel and Savannah was involved by merchants who lived in the edge of the desert who preferred to acquire this kind of trade as an exclusive monopoly. This type of exclusive trade hindered the cowry-currency to appear in other frontiers. Like the other zones, the Atlantic currency zone did not win the battle to penetrate into its neighboring zones. Basically, this currency zone was composed of expensive commodities used as a stock of money relative to its function of distance, its price as a substitute of goods and the strength of its demand. Let us look its component parts: Glassware was too expensive to purchase while the imported cloth couldn't beat the local production because of high transportation cost. In some parts of Sub-Sahara region, Silver coins were accepted as currency but in other parts it was used as jewelry while the iron bars needed a heavy work to produce locally used tools such as spears, hoes, knives and axes. Apparently, there was no political intervention of states or other significant influences that involved the restrictions or any kind of sanctioning against those currency zones to interact themselves inside their economic zones or dominate each other in a natural business transactions or other means of economic influence. Late in $18^{\text {th }}$ century, the cowry currency faced a limited acceptance because slave trade disappeared from historical records. As the researcher explained before, the circulation of cowry currency depended on the slave trade. This time the cowry currency created variations between the frontiers of West African Savannah and Western Sahel which forced the merchants of these regions to create a currency demand from another basket, probably the Atlantic Sea board 
which had successful merchants. Before the cowry currency problem, there were other major variations towards accepting or rejecting the European specie as a currency. In 1720s the British government made considerable improvements introducing its Silver coins as a currency in the Gambia River. From 1720 - 1770, a period of fifty years, the British has been continuing introduction of Silver coins until another fifty years, from 1770 - 1820, the Silver coin was accepted as a currency and replaced large varieties of commodities. The trade export of groundnut in the Gambia River innovated the deep establishment and widely use of Silver coin as a currency in which large number of farmers participated. The French did not win their introduction of Silver coin into Senegal. Along the Senegal River to the north of Sahel, the Sahelian merchants rejected to accept the Silver coins as a currency. Like the cowry-currency, this kind of rejection against the Silver coin created another variation in the Sahel region which connects the West and North regions of the African continent. Later, the guinee exported from India and may be somewhere else came in the game and became the accepted currency in the Atlantic Sea board. The French realized the quality of the guinee as a medium of exchange tried to regulate it and in 1843, the Senegalese government maintained their position by establishing quality standards not against the guinee but as a regulatory law, the government illegalized trading guinee in or importing to Senegal if the currency did not bear the official government quality stamp. In 1847, four years later, the Senegalese government banned or demonetized the Silver and Gold coins in the Senegal River trade. Late in $19^{\text {th }}$ century, the French colonial government reintroduced the Silver coin. The purpose of the reintroduction of the Silver coin was to reinforce the fiat paper money as a regular currency in the French colonies. The introduction of fiat paper money during the colonial era ended (removed) the variations created by currency preferences of Silver and cloth in the Senegambian sub-regions. The cowries and brass manillas of the lower coast of Guinea which were the dominant currencies during the era of the trans-Atlantic slave trade until the commercial revolution of the $19^{\text {th }}$ century. During the colonial era, the British, French and German firms getting help from their colonizer governments banned the cowries and other pre-colonial currencies including the imported monetized metal coins. Why no variation during the colonial era? What happened? During colonial era variation was impossible because the West introduced their currencies with the combination of Military and economic power. Early in the $18^{\text {th }}$ century, the credit practice in trade was common in currency zones of Western Sahel to the north, Senegal and Gambia Rivers; Senegambian sub-region, and the Atlantic European traders. Credit arrangements, forms of stipulation and loan collateralization in the Western Sahel were little known because of two reasons: (1) the contracts were unwritten, and (2) livestock were used to serve in this capacity. Late in $18^{\text {th }}$ century, in the Atlantic seaboard trade, credit practice was institutionalized. The European merchants extended trade goods on credit to the interior regions of Africa through the Upper Senegal River Valley. The arrangements of these loan contracts were publically made with the presence of two witnesses and two responsible individuals incase debtors fail to repay. The slaves in Afro-European territory either trade or house slaves were used as a securitization of these loans. There were also arrangements of second contract negotiations with heavy interest if the initial contracts were unfulfilled. The Europeans were in a position of high liquidity because they knew how to maintain economic rationale relative to the collateral contracts for they were getting immense benefits from the active trade from the Atlantic seaboard to Western Sahel where the Europeans were easily able to market African slaves to the Atlantic world (Americas) (Stiansen \& Guyer, 1999).

Access to credit in Sub-Saharan region is very limited. Bankruptcy of MFIs is widespread due to poor performance of handling financial services, shocks of credit risk, and capital inadequacy. In some countries of SSA region, MFIs are keeping low profile in branchless banking such as mobile phone money because they cannot reach the local stock exchange in order to raise capital and generate income. The depth of financial institutions in SSA countries is shallow. For 
this reason, some Sub-Saharan African countries lowered the capital requirements to establish regional and community banks. In 2013, a number of SSA countries such as Kenya conducted the first investigation of operational efficiency in their Commercial Banks. The study found that SSA Banking Industry was not only weak in liquidity and capital adequacy but also low in corporate governance and e-banking. In 2016, there was a study that investigated the technical efficiency (TE) of 23 Universal Banks in Sub-Sahara region. The study found that only 11 banks (nine foreign and two local) were efficient in their operations. According to survey of financial stability conducted by some SSA Central Banks such as Bank of Ghana (BOG) indicate the SSA Banking Industry experienced a dramatic drop of profitability, from 2006 -- 2011. The above argumentation motivated the researcher to conduct the study of this research.

\section{THEORETICAL AND ANALYTICAL FRAMEWORK}

\section{Theoretical Framework}

Figure 1.1 Theoretical Framework

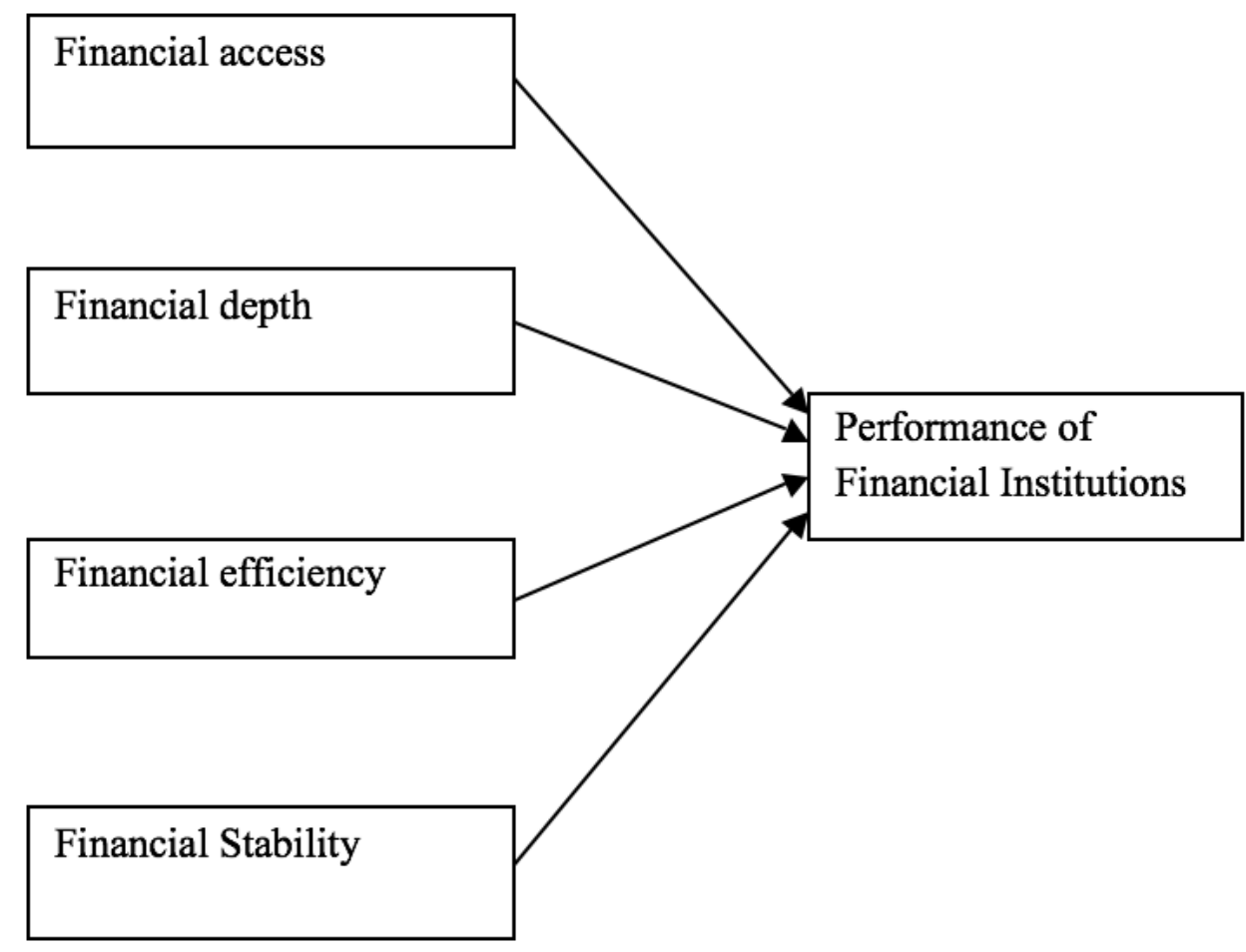

\section{Analytical Framework \\ Institutional Pressures}

The banking industry extremely needs taking serious considerations to integrating sustainability into their lending and investment processes. During 2006, China developed and implemented a green policy that demanded such considerations of sustainability in its banking industry. The Chinese target was a green economy after transforming the banking industry through the financial sector and the aim of their policy was to enable financial institutions to create financial benefits through risk mitigation. The instrument that the Chinese used to implement such policy was institutional pressures (Weber, 2016).

In this episode of this work, the researcher is seeking to present an ample evidence of understanding towards the effectiveness of institutional pressures on the performance of financial institutions. The researcher is not fully convinced that such policy of pressuring can be applied to every part of the globe so; conditions of suitability will be under consideration. Also the researcher intends to investigate whether institutional pressures is going to work or 
has already been effective in other countries outside of China. Finally, the researcher will incorporate the variables of this study: financial access, financial depth, financial efficiency, and financial stability into the theory of institutionalism (institutional theory) to idealize the performance of financial institutions into this end.

The reason why of implementing institutional pressuring to China was environmental problem. China felt endangered because of pollution by heavy productive business industries. The Chinese government worried of the large scale of environmental negligence, intervened the private sector to regulate the primary source of business investment (Chinese financial institutions) to lower the rate of environmental abuse.

In this context of implementing the policy of institutional pressuring, the Ministry of Environmental Protection, getting help from government institution agent; the Peoples' Bank of China (PBC) and another independent Agency; The China Banking Regulatory Commission (CBRC) demanded from the lender institutions to create and present two different rates of interest namely: (1) the adjusted interest rate relative to business industries that neglect or not complied with rules of environmental protection, and (2) reduced interest rate relative to industries of which their businesses are friendly to the environment with modes of loan qualification of (a) restrictions and (b) offers respectively. After a decade from 2007 during the beginning of China's green policy against the credit risk, some researchers like ((Wu \& Zhang, 2018) and (Wang \& Zhong, 2017)) pointed out that Chinese green policy is getting remarkable success, until recently in 2019, when other researchers (Wang, Yang, Reisner, \& Liu, 2019) indicated the otherwise that the effect of Chinese business industry pollution into the very air is still remained high. The sustainability of Chinese green policy in regard of institutional pressuring seems controversial topic, so the researcher has decided to look other parts of the globe.

Early in 1990s, financial institutions gained popularity, drew a fine line among nations in respect of economic development differences, and most important of all, institutions put themselves in the centre stage of the debate towards economic development. Late 1990s, the economic problem of the developing countries has been justified of poor economic and financial institutions. In this respect, the IMF and World Bank worked towards a better governance and loan conditionality. Also donor countries started to attach conditions of better institutional governance to their bilateral aid and this is how Global Standard Institutions (GSIs) came into being or the idea of GSI was first moved from its distance to reach other places beyond its territorial ground. GSIs originated from Anglo-American countries, their primary role is to maximize market freedom and the underlying principles are devoted to protect the property rights at maximum legitimacy. In mid 1990s, the member states of GSIs created various trade and investment agreements based on measurements of bilateralism, regionalism, and multilateralism. The aim of those agreements was to force the developing countries to adopt the standards of GSI organizations. This is how developing countries adopted IPRs (Intellectual Property Rights) of the American Style by WTO (World Trade Organization) and TRIPS (Trade-related Intellectual Property Rights) by the laws of the trade and investment agreements. The North American Free Trade Agreement (NAFTA) is allowing foreign investors to institute a process in law or legal proceedings against host-countries if they are suspected of any action of divesting the title of the private ownership to the eminent public domain. But wait, there is chapter 11 of NAFTA agreement which s designed for an unfavorable particular trait is allowing its member states to regulate corporations including profit-reducing regulations. At this point, everyone is getting to understand what the researcher meant maximum legitimacy. In this way, for many years, developing countries have been subjected to enormous informal pressures by the International Monetary Fund 
(IMF), World Bank, Organization for Economic Cooperation and Development (OECD), the G7, the World Economic Forum and other think-tank groups to force developing countries adopt GSIs. The proponents of GSIs created the international financial press which continuously used to inflict countries of non-Anglo-American financial institutions including many developed countries branding them as lacking of institutional quality. Fortunately, the developed countries of non-Anglo-American financial institutions survived against those negative comments for two reasons: (1) the Anglo-American GSIs predators did not have enough leverage over their prey countries and (2) the background of the forces (the legal system) that defended the existing institutions was strong enough. Unfortunately, the developing countries took the bait. What happened then? The Anglo-American financial institutions pooled their capital markets into the developing countries because of the GSIs infrastructure which significantly increased the power and capital of foreign investors. In the case of Africa, the SSA countries are badly in need of large scale of poverty reduction programs, cheap labor, and industrial capital. The GSIs from Anglo-American countries working inside SSA may never allow this to happen for the reason that their natural characteristics favor the rich over the poor, promote capital over labor, and finance capital over industrial capital (CHANG, 2011). The requirements of GSIs mentioned above is a kind of institutional pressuring which is more different from the Chinese domestic green policy that the researcher discussed previously.

Institutional pressuring may seem to be dynamic but lacks consensus, definition of analysis and attribution, and measurement. But the most important of all, institutional theory and its pressuring policy is too young to justify itself to be the best theory to develop organizations. The most common concept of institutional theory; Isomorphism, dates back to three and half decades (36 years), from 1983 to DiMaggio and Powell. The institutional theory does not categorize its pressures towards target organizations to find consensus or identify distinguished (effective) pressures. This made very difficult to differentiate institutions in regard of their power and behavior. More seriously, the unclear, undefined roles of institutional theory and its policy pressures to organizations contributed ambiguity to the complexity of social processes which blurred how institutional pressures can lead organizations to isomorphism or change (Rosalinde, Woolthuis, \& Taminiau, 2017).

\section{Concepts of Institutional Theory}

Primarily, institutional theory examines management of organizations to differentiate the successful managers from unsuccessful ones. This theory accepts social pressure but rejects economic pressure. There are also technical and institutional pressures. The target of institutional theory is to improve the efficiency of organizations. Firstly, this theory has a concept that addresses the practices of organizations on the bases of adoption and retention towards social pressures for conformity and legitimacy rather than technical pressures on economic performance. This concept of institutionalization points out institutions requires value beyond their intended function. Secondly, the innovation of organizations largely depends on interpretations (communications about the reasons of the adoption) by the adopter rather than the original objectivity and technical attributes. Thirdly, the new institutionalism is the theory that considers the rationalization of myths when the rules of organizations and their appropriate behaviors are not defined by economic rationality due to social pressures. Fourthly, in institutional theory, organizations find their optimal line in the middle way by separating their core functions from adopted ones by announcing accepting norms of institutional pressures (social pressures) and then failing to implement them for organizations are unable to maintain the position of their current productivity if they fully conform to the norms of institutional pressures. Fifthly, to new institutionalism, legitimacy of 
organizations depends on their access-ability to resources, having formal business plan to obtain bank financing, equal opportunity programs allow organizations getting contracts from federal government. Generally, the legitimacy of organizations needs to comply with explicit rules from government regulations and implicit norms from society where organizations operate. Finally, in institutional theory, leading organizations in a business area are pioneers of their followers in business structures, practices, and organizational behavior. This is how the concept of Isomorphism which has three types was born. Coercive Isomorphism is involved by the state to regulating businesses in explicitly articulated rules and laws. Normative Isomorphism which basically addresses proper business practices is involved by morale actors often with implicit rules. In Mimetic Isomorphism, the way of a business to success is not apparent. So, organizations ambiguously attempt to copy other organizations in which they perceived successful or legitimate. The six above mentioned concepts are the foundations of institutional theory. Together, they form a model for organizational behavior that firmly contrasts economic and rational choice models in perspective of firm behavior. In institutional theory, all organizations happen in two categories: (1) technical category in which organizations materialize their resources such as labor and capital, and (2) social category in which they seek symbolic resources such as status and legitimacy (Suddaby, 2013).

In financial access, there are two institutions that are capable of facilitating access to finance: Credit Registries (Credit Bureaus) and Borrowers Legal Rights and Lenders (Secured Transactions and Bankruptcy Laws). These two institutions work together and are dedicated to improving finance allocation. Their primary job is to give up-to-date information to the creditors (lenders) to assess the credit worthiness of clients and facilitate the details of collateralization (loan securitization) and enforcement of claims in the event of default. Generally, these two institutions are designed to facilitate lending and expand financial access to credit. They also check the scope and control the quality of credit information. Credit Bureaus and Bankruptcy Laws work towards better investment climate to help promote economic growth and commerce (Belanová, 2013).

In financial depth, in respect of competition, banks fall into three categories: small banks that mainly work in local markets, medium-sized banks which usually take intermediate position, and large banks that normally operate in international markets. Among small banks, competition is always weak, while large banks engage strong competition but perfect in some countries. The level of ownership concentration of banks accounts for level of asset and insolvency risks meaning higher bank concentration ownership is relative to lower asset and lower insolvency risks. Both customers and granted loans increase market concentration just in two different ways: small amount of deposits by new customers increases the store wealth of deposits of larger banks which leads to market concentration positively. In larger banks, granted loans indicate undertaking higher risk especially when the volume of loan is greater. Market concentration of banks is a mechanism which goes to a different direction meaning when bank competition is high in both loan and deposit markets, banks become more risky and they choose risk-incentive strategy. When there is less competition, banks, abstain risk, and their loan rate is high. On the other hand, in low bank concentration market, borrowers are risk takers, their profits go down and they take more risk. There is no optimal position between banks and borrowers (Hintošová, Demjanová, \& Lešková, 2013).

In financial efficiency, credit institutions install modern information systems to work towards improving their efficiency. Reducing operating costs to promote cost efficiency, and improving organizational structure are indispensable primary steps for efficiency of financial institutions. Introducing new products and services that foster extension of scope in business, merging subsidiaries that engage in the same line of business also reduce cost and improve service and 
quality control. In financial institutions, bank cost, and profit and revenue can be determinants of efficiency. According to previous research studies on bank efficiency, 75 percent were on bank cost. Profit and revenue are more vulnerable than costs and can be subjected to disproportions that affect financial institutions differently. Also financial reforms and competitions have considerably impact on profit and revenue (Kamberoglou, Liapis, Simigiannis, \& Tzamourani, 2004).

In financial stability, there are unprecedented financial disruptions that happen in the process of financial intermediation, severely impacts allocation of savings and may have bad effects on investment opportunities to profit making. Banking system is an important part of financial institutions that involves maintaining financial liquidity, solvency, and absorbing losses from equity of financial institutions. Stability of the banking sector is determined by the following requirement of analysis: identification of capital adequacy, profitability, ensuring assets quality and bank structure, forecasting liquidity problems, and to control currency risk relative to sensitivity. The above mentioned assessment of financial stability takes place under the bank regulation acts by agent supervisors who are only fulfilling the requirements of the bank regulatory rules. Banking system stability does not meant that all banks are stable; it means that banks are resistant to financial crises meaning banks' financial conditions are very good with status of high credit ratings. Instability of financial system does not only affect economic and financial situation of financial institutions but also affects their legal and financial environment (Cichy \& Szunke, 2013).

\section{RESEARCH OBJECTIVE}

The main objective of this study is to examine the performance of financial institutions in five Sub-Saharan African countries. The study is focusing on financial access, financial depth, financial efficiency, and financial stability of five target countries: Kenya, Namibia, Nigeria, Rwanda, and Senegal. The specific objectives of the study are as follows:

\section{RESEARCH QUESTIONS}

1. Is there a broad access of financial services and information of financial services to financial institutions in Sub-Saharan African countries?

2. What is the absolute and systemic size of financial institutions in Sub-Saharan African countries?

3. Are financial institutions in Sub-Saharan African countries both technically and operationally efficient?

4. Do financial institutions in Sub-Saharan African countries have clear and well defined financial stability structure?

\section{LIMITATION OF THE STUDY}

The variables included in this research study are as follows: three variables of financial access, 10 variables of financial depth, 10 variables of financial efficiency, and seven variables of financial stability. ATMs per 100,000 adults, Bank Accounts per 1,000 adults, and Bank Branches per 100,000 adults were included in the study for these are the most significant variables in financial access. There are many other variables of access as well as depth, efficiency, and financial stability that were excluded because of unavailability of data. The banking industry of Sub-Saharan African countries dominates this research work for two reasons: naturally banking industry dominates the financial institutions of Sub-Saharan African countries. Most of SSA countries, the data of non-bank financial institutions (NBFI) are unavailable. 


\section{Financial Access}

\section{REVIEW OF LITERATURE}

Asongu (2017) investigated interactions among information sharing offices, financial access and financial sub-systems. Researchers used Quantile regressions which covered 53 African states from 2004 to 2011. This method specifies changes in the quantiles of the response. The result showed positive relationship between formal financial sector development and information sharing offices (ISOs) improves credit access. Result also indicated that the negative linkage between informal financial sector development and ISOs (Credit registries and Credit bureaus) reduced credit access. Result also revealed that the efforts of credit registries and credit bureaus reduced the risk of information asymmetry. Result explained that in the African context, enhancing financial access depends on two notions; (1) when information sharing was complemented to financial access, there appeared two main constraints: (a) risk features transformation in banks, and (b) constraint of consolidation, meaning liquidity provisions in financial institutions needed mechanism to address problems of liquidity. Together risk transformation and mechanism of consolidation present a little deviation from access to allocation of efficiency. This kind of positive deviation normally happens in the scope of financial institutions in which their primary mission is to improve efficiency. (2) Public credit registries and private credit bureaus, both are expected to improve financial allocation and efficiency. The study concluded that these information sharing offices, their primary job is to educate borrowers to be convenient on the default of their debt and to increase competition among various financial sectors in the financial system which their efforts end up in efficiency rather than access or may be both.

Finau et al. (2016) examined rural dwellers' perception of digital financial services (DFS). The main objective of the investigators was to understand which factors may enhance or impede mobile money adoption. Researchers used survey method and follow up interviews in rural Fijian communities especially low income citizens. This method captures general demographic data and attracts the information on how consumers use mobile money. Results showed failure of mobile money in saving purposes. The mobile money payment research of Fiji was compared to the successful Kenyan M-PESA. The Kenyan Safari-com, the provider of the mobile money service ensured that consumers received positive experiences by monitoring their retail agents closely and regularly. Secondly, they ensured that retail agents maintained enough liquidity to satisfy withdrawal requests of customers and the most important of all, agents were instructed to remind clients that Safari-com is the service provider and not the agents. The creation of positive experience increased disposition of mobile money users to conduct further transactions. Reminding customers the position of the service provider is how Safari-com leveraged the image of its own brand. The study concluded that there are two major causes for the failure of Fijian Mobile Money Services (MMS): lack of agents' liquidity and implicit costs imposed on consumers by agents. The survey on Fiji also noted other problems that can suppress the acceptance and rapid progress of mobile financial transactions for saving purposes of rural dwellers in Fiji. Trust is the most important factor that hinders wide spread of mobile money payment systems. Secondly, most of the users had no previous positive experience with mobile money agents. Thirdly, consumers lack the perception of safety and they are not reliable to using mobile payment systems.

Mehrotra and Yetman (2015) examined financial inclusion related to access of financial services and asked a question whether this feature (access to financial services) is increasing in worldwide level. To answer this question, the researchers used survey method of cross country data. This method made possible the availability of the information related to range of access instruments, namely: bank accounts ownership, borrowing from and saving at a financial institution. The method also displayed various ways that households in 148 countries access to 
formal financial sectors and shares of firms that have credit lines and receive loans from formal financial institutions. Result showed only 20 percent of African adults had financial access to formal financial institutions. In high income countries, the percentage of adult share that are saving money in formal financial institutions is far greater than low income countries. By 2013, in emerging and developing countries, the reports of the same survey showed that the share of small and medium sized firms that gets loan from a bank or have a credit line in formal financial institutions is less than 40 percent. Firms in emerging European countries have greater financial access compared to Asia and Africa. From 2004 - 2012, the industry of African commercial banks had an increase of three to five branches per 100,000 adults of bank account owners while the Caribbean and Latin America had an increase of 11 to 23 bank branches. In Eastern European countries, the number of ATMs per 100,000 adults increased enormously. With the increase of number of deposit accounts per 1,000 adults, the use of financial services increased 30 percent in Columbia and Thailand, and over 80 percent in Mexico and Argentina. The study concluded that in terms of maintaining price stability, Central Banks get benefit from increased financial inclusion. Under interest rates, the share of economic activity increases. Improvements to access on credit with unregulated financial system can increase risk especially risks that affect credit quality.

Nyantakyi and Sy (2015) explained the indicators of banking environment of SSA countries. To review access, penetration, innovation and competition, the researchers used comparative analysis. This method makes sense of similarities and explains differences. Result indicated that less than 25 percent of Sub-Saharan African population has access to formal accounts. The level of financial inclusion of low income African countries is low and the individuals from poor communities have limited access to financial services. SSA region has the lowest level of financial penetration 21 percent compared to Latin America \& Caribbean 34 percent and OECD countries 90 percent. Sub-regions of SSA countries, West Africa has the lowest adult shares of formal bank accounts ownership 14 percent. The SSA Southern sub-region is well penetrated in bank system compared to the rest of SSA region. The measurement of access of bank accounts per 1000 adults, North Africa and Latin America \& Caribbean has more accounts twice than per share adults of SSA population. In OECD, bank accounts as per share adults are four times greater than SSA region. On the other hand, as a technical innovation, the African mobile money payment system especially in East Africa is challenging against conventional ATM machines and electronic payments. Mobile payment has an advantage over ATMs which require regular maintenance, security and liquidity balance. The study concluded to expose some of the reasons why financial access and penetration is the lowest in SSA region compared to the rest of the world. The requirements to open a bank account in some SSA countries is to have access to a formal address, identification card, formal employment with a proof of regular income \& minimum deposit requirement. This kind of banking business is not favoring for the poor. This is not financial inclusion and access for all. This is a distinction between the rich and poor with clear discriminatory barriers.

Cull et al. (2014) assessed financial inclusion strategies of 50 countries of national level households' access to savings mechanisms. To achieve the main objective of their study, researchers employed randomized control trials (RCTs). This approach is highly reliable for assessing micro-level data and its impacts. It also corrects for selection bias. Result showed better improvements when access has been expanded towards consumer credit in national households of South Africa. Expansion of access to credit not only increased income but also improved the status of the borrower and household decision making. In Mexico, researchers found that access to microcredit level reduces precautionary savings and increases consumption levels. In Mongolia and Bosnia, researchers exposed evidence that access not only 
benefits business but also helps the creation of new ones. Results in Mexico and Philippines showed that access to microcredit helps increase the ability of micro-entrepreneurs to coping risk. Result indicated the outcome of savings is more positive than those of credit. Access to savings services for female market vendors in rural western Kenya showed that private expenditures were 13 percent higher with increase of business investment of 38 - 58 percent over female vendors without access to savings account. In commitment savings, business investment in Malawi showed positive effects. In general, accessing savings accounts showed improved results of decision making at the baseline of business investment in the Philippines and other countries particularly for women. The study concluded that financial inclusion positively affected the livelihood progress of the poor. Benefits from small business help poor people to access credit. Formal savings boost household welfare. Payment services reduce transaction costs to enable households manage shocks and risk sharing. For risk mitigation, micro-insurance may become an important mechanism to cope external shocks to enable the poor to escape from poverty but there is a need to address issues of demand and uptake.

UNCTAD (2014) investigated determinants of financial inclusion particularly bank accounts. Researchers used survey method. This approach is useful for testing whether access is expanding to financial services to both individuals and firms. Result revealed that around the world, the variation of adult people held accounts with formal financial institutions has been 50 percent over the age of 15 years in 2011, while disparity of financial services between developed and developing countries exceeded twice as per share adults meaning in developed countries the number of adults held accounts with formal financial institutions outnumbered twice than the number of people in developing countries that can reach financial services. Result also showed that in developing countries, the penetration of bank account depends on income level, groups and regions. The ratio of bank penetration of developing middle-income countries is twice higher than low-income countries. Income inequality has been positively associated with the variation of bank account penetration. The registration of account penetration in East Asia and the Pacific is exceeding the global average, while Sub-Sahara Africa and MENA (Middle-east and North Africa) regions are lagging behind the global average. Result also indicated that 34 percent of firms in developing countries receive bank loans compared to 51 percent in developed countries. The study concluded that the benefits of access can only be useful for those people who have bank accounts because all formal financial activities are related to accounts. Technology and innovative business models can help improve financial inclusion, remove and overcome barriers of financial services and access.

Allen et al. (2013) examined financial access and bank branch penetration in Kenya. Researchers raised two questions: Are there different branching strategies that different types of banks pursue? If there are different strategies, what is the impact on households' access to banking services? To answer these questions, researchers used regressions of micro-level data of household surveys collected by the financial sector deepening Trust of Kenya (FSD of Kenya). The dataset is related to bank branch penetration of all Kenyan commercial banks. This method significantly addresses the biases of potential endogeneity which comes from nonrandom nature of bank expansion. Since the data tends to be homogeneous in institutions of single country, this method is free from obstacles of cross country data. Result showed that a bank called Equity Bank followed a different branching strategy from all other banks. From 2006 to 2009, this bank expanded its services to underserved districts. Such banking endeavor made an increase of bank account holders from 14 percent in 2006 to 23 percent in 2009 . Result also showed that Equity bank integrated with microfinance in a more formal way and there is no government ownership in its shares. Result also revealed that there are three group-cluster of banks; private, government, and foreign banks. Result revealed that all three groups are positively related to district level and the foreign banks have the smallest share. 
Result also indicated that foreign banks targeted the high income population segments and have minimum requirement of 20,000 Ksh to open a bank account. The study concluded that in SSA, underserved population is one of the key obstacles to access. In Kenya, Equity Bank pursuing a different business model led significant improvements to financial services. Institutions with such behavior can bring a solution to the problem of access especially underprivileged population segments.

Mutambanadzo et al. (2013) investigated factors behind the failure and low performance of Microfinance institutions (MFIs) in Zimbabwe. To know reasons of failure and underperformance of 17 MFIs in Bulawayo, Zimbabwe, The study employed survey design. This approach allows collection of primary data in an economical and timely way. Result showed that microfinance institutions failed for funding reasons. Result also showed that MFIs in Zimbabwe had a poor control corporate structure. Result also indicated that the use of Management Information Systems of MFIs in Zimbabwe was not fully implemented. The study concluded that MFIs in Zimbabwe need to establish good governance and sound corporate structures to attract fund. The study also recommended for policy makers to regulate MFIs regularly.

Allen et al. (2011) reviewed African financial systems including Microfinance Institutions in SSA and its sub-regions. To make the review more meaningful, researchers divided the continent into geographic lines namely: North Africa, East and Central Africa, West Africa and Southern Africa. This method of geographic classification gave the researchers more mileage. The result showed in 2009 the average GDP per capita in North Africa was 3,985 compared to other African sub-regions, West Africa GDP per capita averaged 1,126, East and Central Africa, their GDP per capita averaged 673, while Southern African states their GDP per capita average reached 3,793. Result also showed that the West African Economic and Monetary Union (WAEMU) organization has 19 large banks in which their concentration holds 62.7 percent of major market share while 24 medium size banks holds 27.6 percent market share and the rest 9.7 percent market shares holds by a group of 27 small banks. Results also showed that the microfinance institutions have participated in development of the African economy and increased GDP. In some countries, the service impact of MFIs is over 45 million of granted loan. African microfinance has 3.8 million customers affiliated to 90,000 groups. The population of microfinance in Africa is reaching 400 institutions. Over 430,000 loans are granted to microfinance institutions that operate in the region annually. The study concluded that most African states particularly in Sub-Sahara region, their financial system are dominated by traditional banks and informal finance. However, after many years of economic reforms there are tangible improvements of bank development and non-bank finance spreading across Africa.

Honohan and Beck (2007) uncovered and highlighted the factors contributing to lower financial access in Africa. To find the determinants of low access, researchers used survey method. This method gives more in-depth picture of household financial access. Result indicated that in many parts of Africa, the density of population, the communication and transportation system are not fully enough to help financial access reach where it supposed to be. This infrastructural and capacity deficiency increased the cost of market exchange between economic agents. Cost of goods and services also increase as they travel longer distances from the point of acquired. Result also showed that SSA region is geographically and demographically low in bank branch and ATM penetration compared to other regions of the world. In SSA region, there is a high fee barrier to accessing formal bank account. Uganda, Ethiopia and Sierra Leone; opening a checking account needs more than 50 percent per capita 
GDP. Countries such as Malawi, Sierra Leone, Uganda, and Zimbabwe, there are more than 20 percent per capita GDP of annual fees associated with checking accounts while many developing and other advanced economies, their systems have no minimum balance and requirements and associated fees to opening checking accounts. The study suggested that available and low cost credit to productive enterprises is what Africa needs. Extending credit, payment and insurance services to low income people and microenterprises is a necessary step towards full access of financial services. Africa also needs mortgage finance, risk management and diversification such as transparency of price discovery. Not only small firms have difficulties to access credit but also medium scale enterprises is not fully capable to have access to credit and other financial services in which they need to grow.

\section{Measurement of Financial Access}

Beck and Cull (2013) investigated Sub-Sahara banking systems to discover innovations and late developments based on various sets of data. Investigators used randomized controlled trials (RCTs). This method supports assessing different levels of data. Result revealed that aggregated indicators of bank accounts per 10,000 adults and bank branches per 100,000 adults in measurement of access to and use of financial services of both indicators, the African median of only 15 bank accounts per share of 100 adults is lower than other medians of 42 bank accounts of non-African developing countries. The indicator of bank branches per share of adults showed that Africa has 3.1 branches per 100,000 adults while other developing countries have 9.6 bank branches. Result also showed that African indicators in enterprise of formal financing and use of access of households by 21 percent of firms can access to credit lines or receive loans directly from financial institutions compared to other developing countries by 43 percent. Result also indicated the difference of interest rate between LR (Lending rate) and DR (Deposit rate) is higher than other countries, 10.3 percent in Africa, and 8.2 percent outside of Africa. The overhead median of total assets in African financial system is 5.5 percent, higher than other developing countries which their median of total assets relative to overhead costs stood 3.4 percent. In profitability, the ROA (Return on assets) of African banks in the level of median per country is 2.1 percent compared to 1.5 median of other countries outside of Africa. The study concluded that SSA banking sector is characterized high level of stability and low level of fragility. Both technological developments and innovation of financial services helped SSA region leave traditional banking systems behind. However, Africa is looking forward large costs of physical infrastructure.

Beck et al. (2008) measured the financial access by using the demand of the quantity of users towards financial services. Researchers in this field used survey method. This method allowed researchers to make measurement of financial access which is based sub-groups. Basic financial services and the number of users available is an approach to measuring access. Barriers of access both physical and cost can also be used to measure access. Result indicated that small firms face the largest variations of access barriers. Less than 20 percent of small firms use external investment during financing their business operations. Result also showed that in developing countries, geography (physical access) is a major constraint for exclusion of poorer households and small firms. In comparison of bank branches density per square kilometers, Spain which is a developed country has 96 bank branches per 100,000 people of its financial service users and 790 branches per 10,000 Sq Km while Ethiopia and Botswana which is a developing Sub-Saharan African countries has less than one branch per 100,000 people and one branch per $10,000 \mathrm{Sq} \mathrm{Km}$ respectively. Result also revealed that documents financial institutions require for identification to open for example a bank account and high fees to maintain a checking account is a barrier. The study concluded that unbanked households and firms that do not have access to financial services have low income or the risk 
of lending is too high or may be the combination of both which poses a threat of high exclusion rate.

\section{Financial Depth}

Aluko and Ajayi (2017) examined the Sub-Saharan African development and determinants of banking sector. The study used a panel data of 25 countries and covered a period of 18 years from 1997 - 2014. The study employed Generalized Method of Moments (GMM). Results from the model estimator showed that open trade, density of population and bank capital foster banking sector development of SSA region where as liberalization is negatively related to SSA banking sector development. Result also showed that factors of religion, law, and inflation get involved for the promotion of SSA banking sector efficiency while open trade, diversity of ethnicity, and income level are negatively related to SSA banking sector development. The study suggested that financial openness should be separated from trade openness. The study also recommended great caution to be taken for the implementation of this policy because increasing adverse effects from trade and financial openness may affect against banking sector.

Abdulai and Tewari (2017) Examined whether there is a relationship between trade-off and depth of Microfinance institutions (MFIs) by considering institutional factors of Sub-Saharan African countries. The study employed methodology of correlation and regression analysis with random effects. The random effects (RE) approach produces accurate estimations. The panel data covered 619 observations of 71 MFIs from 10 countries. Result revealed the existence of trade-off between depth and outreach of Microfinance institutions. Results also revealed that institutional factors of staff borrowers, portfolio at risk, operating expenses to assets, interest rate, and gross loan portfolio are positively related to outreach of microfinance institutions in Sub-Saharan African countries. The study suggested the MFIs in SSA region need a technological cost saving development that can enable MFIs in the region to operate efficiently in a sustainable environment.

Alpha et al. (2016) investigated the economic growth in West African countries relative to intermediation of financial services. The study used panel data for a period of 28 years from 1985 - 2013. The study also employed financial intermediation theory and growth of Diamond and Dybvig in 1983 and Romer in 1986. Result showed high interest spread and inflation rates. Result also revealed that there is a positive relationship between M2 of broad money, M3 of financial intermediation level and economic growth in West Africa (WA) region. Result finally indicated that inflation, interest rate spread, and credit supply negatively related to economic growth in West Africa region. The study suggested for the policy makers to formulate suitable growth policies for the financial intermediation and financial development and economic growth of the West African region.

Obamuyi (2013) investigated the Nigerian bank profitability relative to variables of bank capital, management expenses, bank size (depth), interest income and condition of economy. The study employed regression model of fixed effects with a sample of 20 banks of a data panel which covered for a period of seven years from 2006 - 2012. This method allows to overcoming of banks' heterogeneous characteristics and unobservable constants. Result showed that all variables of bank capital, management expenses, size, interest income and economic condition was positively and significantly related to Nigerian bank performance and economic growth. The study suggested for policy makers to create an environment that Nigerian commercial banks can increase their capital to contribute higher economic growth. 
Akinlo and Egbetunde (2010) examined the relationship between economic growth and financial development in Sub-Saharan African countries. The data covers a period of 25 years from 1980 - 2005 with a sample of 10 SSA countries. The study used Vector Error Correction Model (VECM). This approach allows measurement of tendencies to make variables return to the equilibrium. Result showed that there is a positive in long-term relationship between financial development and economic growth of Sub-Saharan African countries. Result also showed that Granger causality of financial development is positively related to economic growth in countries of Congo Republic, Nigeria, Gabon and Central African Republic whereas Granger causality of economic growth is positively related to financial development in Zambia. Result also showed positive relationship in both directions between variables of economic growth and financial development in countries of South Africa, Sierra Leone, Chad, Swaziland and Kenya. The study concluded with a recommendation to developing financial sector of Sub-Saharan African countries by using suitable macroeconomic and regulatory policies.

\section{Measurement of Financial Depth}

Nouaili et al. (2015) examined the internal and external factors to measure bank performance in Tunisia after reforms in the financial sector. To know the impact of bank performance and financial reforms the study employed linear model of regression analysis developed by Bourke in 1989 and methodological approaches developed by Demirgüç-Kunt and Huizinga in 1999 and Dietrich and Wanzenried in 2011. Result showed that there is a positive relationship between variables of quotation, capitalization, privatization and bank performance. Result also showed negative relationship between bank performance and variables of concentration, bank size and efficiency. Result indicated that business cycle is negatively related to inflation rate. Result also indicated that Tunisian business cycle is suitable to bank performance. The study concluded that Tunisian financial reforms were not successful to make positive contributions to bank performance.

Hagendorff et al. (2012) investigated the relationship between bank risk taking and systemic size measured as the ratio of bank assets to GDP. The study used linear regression model with econometric approach. This method separates bank specific factors and bank risk taking. Result indicated that largely systemic banks (systemic size) do not affect bank risk taking during both normal and crises times. Result showed bank bad behavior of prospective capitalization. In respect of banks' balance sheet, large banks were doing less income diversification while their debt was less subordinated. The result of the study pointed out that systemically important banks were aggressive risk takers during recent crises of 2008 -- 2009. The study concluded that banks were attempting large scale of shareholder maximization value during before the crises. The study also suggested that governments restrict bank risk taking behavior especially large systemic (systemic size) banks by employing contingent regulation.

Anayiotos and Toroyan (2009) evaluated the impact of institutional factors in the financial sector development of Sub-Saharan African countries. To address the relationship between institutional factors and financial sector development, the study employed Data Envelopment Analysis (DEA). This approach allows the comparison of decision making units (DMUs). Result showed that institutional factors had a greater impact on financial depth whereas the same factors had a lesser impact on profitability and quality when measured the services of financial sector development by return on equity (ROE) and non-performing loans (NPLs). Result also indicated that size of credit information is strongly related to the ratio of NPLs. The study concluded that policy suggestion of the findings is suitable to individual countries and country groups. 


\section{Financial Efficiency}

Spulbăr et al. (2015) estimated the cost efficiency and performance of Cooperative and Savings banks in nine countries. The study considered specific variables that influence the levels of efficiency of Cooperative and Savings Banks. The sample consisted of an unbalanced panel of dataset of 9,352 observations which covered a period of seven years from 2005 2011. The study used Stochastic Frontier Approach (SFA). This method allows for the presence of random error term. It also allows deviations from the efficiency frontier to be related with inefficiency. Result revealed high level of efficiency relative to both Cooperative Banks from Switzerland and Savings Banks from Norway and Sweden. Result also showed that both risk and performance lead to different directions; higher risk implies the growth of inefficiency levels while performance lowers the levels of inefficiency. Result also revealed that the levels of inefficiency increase when the rate of GDP gets higher. Result also indicated that savings banks and smaller cooperatives successfully outperformed in cost management and efficiency compared to large banks. The study concluded that commercial banks had the chance to get higher market share which made possible for these institutions to have access to more cheaply financial resources during their economic growth. The study suggested for the management of savings and cooperative banks to promote cost efficiency measures and adopt more cautious policies. The study also suggested for the authorities to regulate both types of financial institutions and particularly encourage savings and cooperative banks for their long term strategy of lending.

Fiordelisi et al. (2010) analyzed the impact of efficiency on bank risk. Researchers examined whether bank capital has an effect on the relationship between bank efficiency and bank risk. They also tried to view the inter-temporal relationship between bank capital, bank risk, and bank efficiency. To do this, they took large sample of commercial banks operating in the European Union. The study used Granger Causality method. This approach allows researchers to take unique time-ordered tests and find the relationships between a pair of variables. It also positively affects inter-temporal relationships between variables. Result revealed that bank efficiency improvements is relative to the increase of bank capital while banks' future risk increases with the relativity of cost reduction and revenue efficiencies. The study suggested that there is a possibility of higher risk expectations and subdual capital positions in the near future regarding banks that lag behind their levels of efficiency.

Desrochers and Lamberte (2003) investigated if Cooperative Rural Banks (CRBs) have the ability to control Agency Costs. To take this test researchers use two different types of efficiency, namely: cost and alternative efficiency. The study was based two different propositions; cost agency may reduce the efficiency and adequate corporate governance scheme may improve efficiency. The study used Distribution Free Approach (DFA) and Stochastic Frontier Approach (SFA). This method allows decomposition of errors between randomness and efficiency and supports the conclusions drawn from the analysis. Unfortunately, the researchers couldn't be able to present conclusive evidence on their findings towards corporate governance relative to improvement of efficiency of CRBs in Philippine. However, result revealed the presence of large stakeholders and managers' compensation theory. On the second proposition, researchers found direct and positive relationship between the reduction of efficiency and cost agency. So, the most efficient CRBs in Philippine are the ones successfully controlled the cost agency. Researchers also confirmed that rural CRBs in Philippine are the most profit efficient financial institutions in the country. The study concluded that CRBs in the region maintained regular cost efficiency for they are able offering quality services with higher fees. Small CRBs managed setting better interest rate policy to lowering both loan and deposit rates. 


\section{The Increasing Role of Financial Efficiency}

Niţoi and Spulbar (2015) investigated the cost efficiency of commercial banks in six emerging countries from Central and Eastern Europe over a period of seven years from $2005-2011$. The study used Stochastic Frontier Approach (SFA) Model. This method allows decomposition of error into two parts: classical random error and one-sided error that is used to measure nonnegative inefficiencies. Researchers believed that their analysis was important in regard of stability. They argued that bank efficiency especially commercial banks became important for banks stability. To prove this positive deviation, the result of the investigation showed the existence of high macroeconomic stability that supported the efficiency of commercial banks. The higher the risk taking of banks the higher the inefficiency of banks, the lesser the liquidity and solvency rate of banks with a higher credit risk the more the banks become inefficient. When researchers analyzed the evolution of cost index, they reported that the overall banking system managed to increase their efficiency levels until 2008. During 2009, countries like Poland, Romania, Russia, and Hungry, the efficiency level of their banks started to decrease. In Bulgaria and Czech Republic, Researchers documented stagnation of efficiency index. The study concluded the banks with the best performance maintain the highest levels of efficiency. The study also suggested the higher the growth of interest margin the higher the levels of inefficiency.

Castellanos and Garza-García (2013) studied the evolution of efficiency of Mexican banking sector for a period of 10 years from 2002 - 2012. The study also analyzed the degree of relationship between bank competition and bank efficiency. To estimating efficiency, this study employed non-parametric methodology, DEA (Data Envelopment Analysis). To assess the degree of competition, researchers used Boone indicator and other determinants of bank efficiency. During investigation, the main result indicated an increasing trend of efficiency in the Mexican banking sector. During observations, researchers found a direct relationship between bank competition and bank efficiency. Researchers also documented that market capitalization index, loan intensity and market share increase efficiency while non-performing loans and noninterest expenses decrease efficiency. When the system's average efficiency trend was observed, the result of local Mexican banks showed superiority in efficiency over foreign banks. The study concluded that during 1995, the Mexican bank competition and bank efficiency became a subject of interest and debate. May 2013, Mexico stepped into financial reform initiative in which its introductory behavior revealed pure competition among largely foreign owned banks. The reform initiative became prolifically successful to reducing the cost of borrowing. The conditions of Mexican banking sector has been changing for over the last 20 years that helped the economic theory to predict efficiency and competition of Mexican banking sector.

Saqib (2013) examined the efficiency of financial sector on economic growth for a group of developing countries and the impact of their development. The study used a sample of developing countries with a cross-country data for a period of five years from $2005-2009$. The study employed sensitivity analysis with EBA (Extreme Bond Analysis). This method puts more confidence on the conclusions. Result indicated that the efficiency of financial sector of developing countries is positively related to the economic growth. Result also revealed that efficiency positively and significantly affected both financial development sectors and economic growth of 50 developing countries. Result finally showed the relationship between efficiency and financial sector development will support economic growth. The study suggested that financial sector development is to be seriously taken as a primary strategy to economic growth in the long run. 
Anayiotos et al. (2010) estimated the relative efficiency of the banking industry of emerging Europe in three periods: before the economic boom, before, and after global financial crises. The study employed Data Envelopment Analysis (DEA). This method easily identifies ways in which inefficiencies increase. Result revealed that efficiency scores was strongly connected to the level of development of the host countries before financial crises. Result also indicated that bank efficiency increased during the pre-crises economic boom in the region of emerging Europe. Result also showed because of their operational environment, the foreign banks in this region are less efficient compared to their domestic peers. The study suggested expansion of credit could lead to inefficiency.

Brack and Jimborean (2009) examined the efficiency levels of the 10 largest banks in Europe (France, Germany, Italy, Spain, \& the United Kingdom) and the United States. The examined data covered 12 years period from 1994 - 2006. The study employs Data Envelopment Analysis (DEA). This approach easily determines the scores of cost efficiency for banks during analysis. Result showed improvements in cost efficiency of French and Spanish banks compared to their peers in other European countries. Result indicated that the bank specific variables of macroeconomic environment, regulatory regime and the non-bank financial sector development contributed the efficiency scores obtained during research investigations. Result also showed that the highest cost efficiency scores were recorded by recently capitalized banks with high ratio of tier 1 capital. However those banks were operating in countries with lower GDP per capita. The study suggested analyses of cost efficiency should be carried out in other countries that share similar and different bank characteristics.

Said et al. (2008) analyzed the performance of financial institutions and efficiency of Malaysian banking industry especially M\&A program of commercial banks. The study covered for a period of seven years from 1998 - 2004. To answer the question of impact of pre and post merger program, the study used double analysis: Data Envelopment Analysis (DEA) and analysis of panel data regression. This method allows examining productive and technical efficiency of commercial banks. Result indicated that mergers program did not enhance the productive efficiency of the Malaysian banks. Results also revealed that Malaysian banks are focusing intermediation banking activities to generate high net interest income. The study suggested that Malaysian Commercial banks are oriented to loan loss reserve policies. Such policies lead banks to inefficiencies and negative impact of interest earning ratio variable against ROE.

Rivas et al. (2006) investigated whether derivatives affect the efficiency of Latin American banking industry. The data sources are from 182 banks from Brazil, Chile, and Mexico. The study used Data Envelopment Analysis (DEA). This approach allows examining sensitivity of the efficiency scores. Result revealed that the increase of Latin American Bank Efficiency is relative to the use of derivatives. Researchers also found that bank efficiency levels increased largely. Result also indicated that there is a negative relationship between regulatory \& institutional constraints and bank efficiency in Latin American countries. The study suggested that the outcome of this study is important to Latin American Bank Executives, investors, and most important of all the policy makers.

Amel et al. (2002) reviewed the main sector of the financial industry such as investment banks, commercial banks and asset management and insurance companies. The study used mergers and acquisition data for a period of 20 years from $1982-2002$. This method allows measurement of efficiency gains from consolidation. Result showed mergers and acquisitions (M\&A) do not qualify for the efficiency of commercial banks especially profit and cost 
efficiency. There is a little evidence that showed M\&A favors for the side of scale of economies of commercial banks. Result did not show any clear existence of economies of scope when commercial banks get involved into M\&A consolidation programs. Result also revealed little benefit to gaining economies of scale and there is also little evidence to gaining managerial efficiency. The study concluded that the expectations from consolidation of the commercial banks industry ended in contradictory relative to quality of management in scope and scale of economies.

\section{Measurement of Financial Efficiency}

Hamid et al. (2017) measured the Malaysian bank efficiency by considering non-performing loans (NPLs). The study contained efficiency measurement of 21 Malaysian institutions (Eight domestic commercial banks and 13 foreign banks). The data covered for a period of 10 years from 2005 - 2014.To measure the performance of Malaysian Financial Institutions especially the efficiency of banking system, the study employed Directional Distance Function (DDF). This method allows the separation of desirable and undesirable outputs. The study also used Data Envelopment Analysis (DEA). The result showed that the DEA in technical efficiency of domestic Malaysian banks is marginally higher compared to their foreign peers. However, when DDF technical efficiency analysis with NPLs was incorporated, the Malaysian foreign banks showed slightly better improved results than domestic banks. The study suggested encouragement towards better understanding of bank efficiency for the regulators and policy makers of the financial system.

Rahim (2016) measured the technical efficiency of Malaysian commercial banks. The researcher also tried to explore the relationship between banking competition and efficiency. The data of the study covered a period of 15 years from 1996 - 2011. To explore the efficiency of Malaysian commercial banks, the study employed Data Envelopment Analysis (DEA). The study also used Learner Index to estimate bank competition and Granger causality method to find out whether competition fosters efficiency. The result of the study revealed evidence denoting increased level of concentration among Malaysian Commercial Banks with lower competition. However, causality tests showed that technical efficiency has been positively related to some effects of competition. The study concluded that some Malaysian commercial banks could never lower their cost to reach high level of efficiency. Those banks have never been exposed to competition because of their market power.

Miklaszewska et al. (2014) examined the post-crises regulatory environment on bank efficiency and bank stability of central and Eastern European (CEE) banks. Regarding the inefficiency and instability of the global banking system, the study raised an important question related whether CEE banks could operate in unstable environment. To answer this question, the study employed Data Envelopment Analysis, H-Statistics and Z-Score Index. The analysis of the study of bank performance was separated into two periods: the pre-crises period characterized market expansion \& dynamic credit, and the period of recent financial crises of 2007 - 2009. Result revealed that the latter phenomenon forced bank policy regulators and banks themselves to rethink business strategy and bank competition issues. Result also indicated when bank efficiency and performance was measured; scores of Variable Returns to Scale (VRTS) were higher than Constant Returns to Scale (CRTS). The study concluded that CEE banks did not need basic restructuring after 2008 financial crises because Central and Eastern European States successfully completed restructuring program during between $1990-1999$.

Fang et al. (2011) examined profit and cost efficiency of banking sectors in six SSE (SouthEastern Europe) transition economies. The data of study covered for a period of 10 years from 
1998 - 2008. The study employed Stochastic Frontier Approach (SFA). This approach separates inefficiency term from residuals. Result revealed 68.59 percent of average cost efficiency and 53.87 percent of average profit efficiency of SSE banks. Result also indicated that foreign banks in SSE countries showed superiority in profit efficiency but lower averages in cost efficiency while government banks revealed lower profit efficiency. Result also revealed that there is a positive relationship between the degree of bank competitiveness and cost \& profit efficiency. The study suggested the creation of competitive environment of bank efficiency is an important big stride taken towards minimizing the gap between SSE countries and the rest of EU.

Kablan (2010) examined the determinants of SSA banking systems towards efficiency and raised a question about the low levels of SSA financial development. To answer this question, the study used Stochastic Frontier Approach (SFA) and Generalized Method of Moments (GMM). SFA allows the determination of cost frontier while GMM is used to explain SSA financial developments. The result showed that African banks are cost efficient but low in financial development due to effect of political and economic environment. The result on SSA banking implied that banks could play an important role of financial intermediary by transforming deposits into loans for investment. Result also revealed that improvement of efficiency in SSA banks depends on better credit environment which can be obtained through better judicial and legal processes and access-ability of borrowers' information through public registries and credit bureaus. The study concluded that Sub-Saharan African Countries have the possibility to developing the role of their financial intermediation meaning transformation of deposits into investment but this depends for the consideration of other external factors rather than internal.

Siudek (2008) measured the efficiency of polish commercial and cooperative banks and EU member states. To determine the efficiency levels, the study explored bank specific and other macroeconomic factors. The study used macroeconomic data for a period of 10 years from 1997 - 2007. To measure efficiency, the study employed comparative analysis with multiple regression models. This method allows comparison of two or more banks balance sheets. Result showed that commercial banks of Poland enjoy high levels of ROA and ROE compared to cooperative banks. The research findings also showed that Poland has superiority in efficiency over EU member states. The study concluded that polish banks efficiency measured by variables of ROA and ROE was shaped by macroeconomic environment and bank specific factors.

Allen and Engert (2007) investigated the bank efficiency of Canadian financial services. The study employed H-Statistic methodology. This method allows statistical measurements when changes of firm revenues are relative to the changes of input prices. Result showed that Canadian banking industry is practicing monopolistic competitive market. Result also revealed that the efficiency of Canadian financial services has benefited from regulatory changes in the past. Result also indicated that Canadian technological changes in its banking industry such as automated teller machines (ATMs) and investment of employee training lowered the level of cost inefficiency. The study suggested the efficiency of Canadian banking industry on one hand is relative to its service producers. On the other hand, larger efficiency gain is becoming more possible.

Zago and Dongili (2006) estimated technical efficiency (TE) of Italian banks by considering bad loans. The study employed Directional Distance Functions (DDF). This method incorporates bank credit quality into the bank technology and estimates efficiency of banks 
considering credit risk. Result showed that banks were credited to increasing outputs and decreasing resource use and bad loans meaning when bad loans decreased, technical efficiency significantly increased. Furthermore, result revealed those Italian banks which were successful in credit quality, their efficiency estimation was more important. The study suggested that the variable of bank credit quality is equally necessary for the evaluation of banks' performance as regulatory purposes.

Berger and DeYoung (1997) investigated loan quality, cost efficiency and bank capital and the relationship among the three variables. The study employed Granger causality method. This approach either produces consistency or inconsistency with hypothesis. Result revealed higher operating costs because of hard dealings of non-performing loans. Result also revealed when cost efficiency declines non-performing loans increase because of poor management for loan portfolio. Result also indicated when X-efficiency increases, the ratio of non-performing loans also increase. The result also showed capital asset pricing (CAP) ratio and bank portfolio risk increases at the same time because of high problem loans. The study concluded that the relationship between cost efficiency and quality of the loan is double sided. The current researcher is suggesting that authors anxiously looked for an ample method of reconciliation of NPLs and productivity efficiency of financial institutions especially banks. Due to this ambiguity, researchers are no sure whether cost efficiency can be an important indicator to measure both bank and loan problems in the future.

\section{Financial Stability}

Mufandaedza (2017) identified the determinants of Zimbabwean commercial bank lending strategies during post dollarization era. The study used random effect model to estimating annual panel data. This approach explained the lending behavior of commercial banks in Zimbabwe. The data covered for a period of seven years from 2009 - 2015. Result showed that there was a positive relationship between loan supply and other variables of non- performing loans, deposits, and cash reserve requirements. Result also showed that GDP, return on assets and inflation were significantly relative to the bank lending strategy where bank deposits positively related to large amounts of loans provided by commercial banks. The study suggested for the economic policy makers to implement a medium and long term deposit strategies to promote loans in all economic sectors.

Kagoyire and Shukla (2016) examined the credit management effects against commercial banks financial performance in Rwanda. The study is based case study and employed survey design in descriptive statistics with a sample of 57 employees. The study also used questionnaire. This approach allows collection of primary data from respondents. Result indicated positive relationship between performance of commercial target banks and variables of control of credit risk, policy collection, and appraisal of clients. Result also showed that the variable of policy collection had significant effects on the bank performance where as other policies such as stringent is significantly relative to debt recovery. Result also indicated the lenient policy had a very low effect on the financial performance of Rwandan commercial banks. The study suggested for the banks on the study to rearrange their stringent policies to become more effective to debt recovery.

Okungu et al. (2014) investigated the performance of Kenyan savings and credit cooperatives (SACCOs) and commercial banks by using the effect of personal loans. The study also investigated how commercial bank loans affect SACCOs and volume lending from banks to SACCOs. The study also examined how the members benefit from competition between SACCOs and commercial banks and finally the study tried to indentify the factors that make members of SACCOs to borrow from other financial institutions. The study used questionnaire 
method to prepare primary data. It also used secondary data from financial statements and reports. Result showed that loans from commercial banks had no major effects to SACCOs. Result also showed loans, membership and savings increased over the years. Results finally indicated that 51.5 percent members agreed get benefits of loan from competition between commercial banks and SACCOs. The study suggested for the policy makers to give SACCOs equal opportunities of commercial banks for their fund requirements.

\section{Measurement of Financial Stability}

Akande and Kwenda (2017) measured the competitive environment and assess the determinants of Sub-Saharan African banking sector of 440 commercial banks. The study employed Learner Index and Generalized Method of Moments (GMM). The Learner Index Approach allows best estimations of bank competition measurement. The study covered for a period of 10 years from 2006 - 2015. Result revealed the existence of monopolistic competitive banking market. Result also showed that the power of bank competition depends on the level of bank capital with consideration of bank specific variables. The study concluded that SSA region enjoys competitive environment of banking market. The study also recommended for the policy makers of the region to make sure the implementation of any other necessary economic variables that can support such environment.

Brei et al. (2017) investigated the SSA bank competition by using bank non-performing loans which is a bank credit risk measurement. The study which used bank data and a sample of 221 banks from 33 countries covered for a period of 15 years from 2000 - 2015. The study employed Learner Index method which allows best estimation of bank competition measurement. Result indicated non-linear relationship between bank credit risk and bank competition meaning the increased bank competition can lower the bank credit risk. Result also revealed if extreme banking competition happens, there may be adverse effects which will outweigh the positive effects of competition. The result also indicated that the bank credit risk in Sub-Sahara Africa is not only affected by macro-economic determinants but also regulatory environment. The study suggested the findings can help policy makers understand how to formulate prudential and regulatory frameworks suitable to the needs of developing SubSaharan African countries.

Nikolaidoua and Vogiazas (2017) identified and measured the variables of credit risk of five Sub-Saharan African countries: Namibia, Zambia, Uganda, Kenya, and South Africa. The study used Auto-regressive Distributive Lag (ARDL). This approach allows co-integration. Result revealed that in all five countries, non-performing loans enormously decreased because of money supply increase. Result indicated that in Uganda and South Africa, bank specific variables took an indispensible role to lower the NPLs relative to bank credit risk while country specific variables directly affected the cases of Kenya and Zambia. To make sure the financial stability, the study compares between SSA countries and Central East and South East European (CESEES) countries. The study suggested for policy makers of CESEES countries to learn lessons of strengthening of bank balance sheets from SSA countries.

Chege and Bichanga (2017) investigated the performance of Kenyan commercial banks by using non-performing loans (NPLs) variable as a measurement. The study used both empirical design and survey method. This approach produces an output based on statistical information that might interest to a certain groups. Result showed that NPLs was positively and significantly related to the performance of Kenyan commercial banks when return on assets (ROA) was considered as the dependent variable. Result also showed that bank specific factors of depth, operating costs and capitalization significantly and positively related to bank 
performance when ROA was considered as the dependent variable. Finally, result indicated liquidity was positively but insignificantly related to bank performance. Researchers concluded that the study helps management of Kenyan commercial banks to control the growing problem on non-performing loans.

Ayat (2016) explained the primary causes of financial crises of commercial banks in South Sudan. The study employed descriptive survey design with a target population of 248 bank employees. The study also used questionnaire with a technique of sample stratification. The questionnaire method allows collection of primary data from respondents. Result revealed lack of loan securitization policies, lack of clear policies of bank governing and bank operations, and non-experienced employees of banking administration and management contributed the financial crisis of commercial banks in South Sudan. The study concluded with recommendation towards commercial banks management in Nile region, South Sudan. The study suggested loan collateralization policies and employee training and management to foster the image of commercial banks.

Ugoani (2015) examined the relationship between Nigerian bank failure and credit risk management. The study employed survey method and Chi-square statistical method for data analysis. This approach allows for selection of the interested respondents in the sample from the population. Result showed that Nigerian bank failure is relative to poor credit management. Result from the Nigerian literature also revealed that there is a relationship between poor corporate governance and Nigerian bank failures. The study concluded that the relationship between bank failure and poor credit management is critical one. The study suggested establishment of sound credit and risk management policies. The study also suggested issues of executive member credibility and the establishment of fine-tuned policies of macro and micro economic prudential guidelines.

Babajide et al. (2015) forecasted the Nigerian bank failure before it occurs by using survival analysis. To indentify financial distress symptoms that can lead failure of financial institutions especially commercial banks, the study employed non-parametric estimator of Kaplan-Meier and parametric survival analysis with Cox Proportional Hazards regression Model by using financial statements from Nigerian banks. The latter approach allows a probability range from 0 to 1 . This range shows the risk of bank failure. Their panel data covered a period of eight years from 2003 - 2011. Result revealed the type and characteristics of bank failures in Nigeria; the triple factor of high Non-performing loans, asset leasing problems and high operational expenses led banks to fail. Result also showed specialty of Nigerian banks decides the bank average time of survival. The study suggested that there are other variables such as: internal efficiency, practicing good governance in corporate and proper management that have a greater importance for the Nigerian banking industry.

Uzokwe and Ohaeri (2014) described the causes and effects of bank distress in Nigeria. The study raised questions about distress, its factors and solution. To answer these questions the study used questionnaire and interview method to collect data from 106 respondents from five commercial banks in Imo state of Nigeria. The questionnaire method allows reaching large number of people easily and economically. Result revealed 64.4 percent of political indeterminacy and institutional factors represent Nigerian Bank distress and failure. Result also noted fraud history of Nigerian banks as follows: in 1997 forgeries and fraud sky rocketed to 804.2 million, 1999 ( 388.6 million), 2000 ( 411.8 million), 2001 ( 1419.1 million), 2002 ( 3399.4 million), 2003 ( 11011.4 million), and 2004 ( 377.9 million). Eight years period from 1997 - 2004, the Nigerian banking industry experienced an overall loss of 17,917.4 million in fraud and forgery. The study concluded that the Nigerian bank distress 
creates loss of confidence in the public which results large amounts of withdrawals because of public panic. The study also noted that religious and tribal crises also affect Nigerian bank stress.

\section{Research Design}

\section{METHODOLOGY}

This study adopted descriptive research design to achieve reliable answers of the research questions on the performance of financial institutions. The descriptive nature of this study attempted to describe a subject matter by identifying and investigating problems of secondary data (Tayie, 2005). This study used quantitative approach which determines relationship between independent and dependent variables to measure performance (Kothari, 2004). The oriented methodology of this research is presented by survey strategy to investigate the secondary data. The main purpose of the survey strategy is to discover the description of the secondary data (Oso \& Onen, 2008). The justification of choosing survey strategy is that survey is a popular common strategy for descriptive research and suggests possible reasons for any particular relationship between variables and gives the researcher the ability to control over research process (Saunders, Lewis, \& Thornhill, 2009).

\section{Research Population}

The population of the study (Sample frame) came from African continent especially SubSaharan African financial institutions. For now there are at least 47 Sub-Saharan African countries.

\section{Sample Size}

According to Trochim \& Donnelly (2007), a sample refers to the actual units from the population to participate in the study. The sample unit of this study is geographical and it is composed of five Sub-Saharan African countries namely: Kenya, Namibia, Nigeria, Rwanda, and Senegal. The justification of the selection of these five countries as a sample is the availability of their data and mixed per capita GDP.

\section{Instrument}

The secondary data used in this study is retrieved from Global Financial Development Database (GFDD). This data is part of a larger effort in which World Bank provided open access to its research. The GFDD is based on a framework of $4 \times 2$ meaning four proxies of financial access, financial depth, financial efficiency, and financial stability and two dimensions namely; financial institutions and financial markets (Čihák, Demirgüç-Kunt, Feyen, \& Levine, 2012). The researcher selected $4 \times 1$ meaning the four above mentioned proxies to measure the performance of financial institutions.

\section{DATA ANALYSIS}

\section{Measuring Central Tendency of Data Distribution}

This study depends on computation of Mean for a given data. According to (Singh, 2006), measuring the central tendency of data distribution, Mean is the most reliable and accurate measurement compared to Median and Mode. When Sample is drawn from the same population and there is no or less fluctuation, Mean has the greatest stability. Therefore, where a reliable and accurate measure of central tendency is needed, we compute Mean for the given data. When researchers need to know statistics of Standard deviation, Correlation coefficients, and un-standardized (B) beta coefficients; computation of Mean is inevitable for the given data. Readers of this detailed outline should know measures of central tendency are Mean averages. 


$$
\bar{X}=\frac{\sum X}{N} \text { of proxy } 1
$$

Sigma X or (Sum of X) is represented overall mean of some grouped variables meaning sum of all the values in the sample. $\mathrm{N}$ is the number of measurements but here $\mathrm{N}$ is denoting number of years. In this way, central tendency of data distribution is measured by using Mean averages. The next step is regression analysis.

\section{Regression Analysis}

Weighted Least Squares (WLS) is a parametric regression analysis. It is an extension of Ordinary Least Squares Regression. In WLS, negative or non-negative un-standardized (B) coefficients are attached to data points. At this stage, the data points we are talking about are the Mean averages. The justification to using Weighted Least Squares (WLS) is that the researcher is making count on homoscedasticity and heteroscedasticity. Weighted Least Squares can be used when the Ordinary Least Squares (OLS) assumption of constant variance in the errors is violated. WLS is also favorable for that the residuals of Mean, Median, and Mode can be reduced to lower the error of the model result. WLS is an efficient and ideal way to make good use of small data sets. It also has the ability to provide various types of easily interpretable statistical intervals for optimization, estimation, calibration, and prediction. At last the data points used in this project has different qualities which necessitate the employment of WLS.

\section{Development of Financial Institutions Performance Model}

The following regression model is fit for the study of this project. The model shows the data of this study has different qualities and it perfectly suits the measures of central tendency (Mean averages) of financial access, financial depth, financial efficiency, and financial stability.

$$
\begin{aligned}
& Y=\sum_{v=3}^{p r 1} F A(\mathrm{~B} 1)+\sum_{v=10}^{p r 2} F D(\mathrm{~B} 2)+\sum_{v=10}^{p r 3} F E(\mathrm{~B} 3)+\sum_{v=7}^{p r 4} F S(\mathrm{~B} 4)+\varepsilon \\
& Y=\sum_{v=3}^{p r 1} \mathrm{X} 1(\mathrm{~B} 1)+\sum_{v=10}^{p r 2} \mathrm{X} 2(\mathrm{~B} 2)+\sum_{v=10}^{p r 3} \mathrm{X} 3(\mathrm{~B} 3)+\sum_{v=7}^{p r 4} \mathrm{X} 4(\mathrm{~B} 4)+\varepsilon
\end{aligned}
$$

The model has the following interpretations

Where:

$\mathrm{Y}=$ Performance of financial institutions

$\mathrm{FA}, \mathrm{X}_{1}=$ Financial access

$\mathrm{FD}, \mathrm{X}_{2}=$ Financial depth

$\mathrm{FE}, \mathrm{X}_{3}=$ Financial efficiency

$\mathrm{FS}, \mathrm{X}_{4}=$ Financial stability

$\mathrm{B}_{1} \ldots \ldots \ldots . . . . . . \mathrm{B}_{4}$ is the sensitivity of the un-standardized beta $(\mathrm{B})$ coefficients

$\operatorname{Pr}^{1}$...... $\operatorname{Pr}^{4}$ on upper boundary of the formulae denote the four proxies of this study

$\mathrm{V}=3, \mathrm{~V}=10, \mathrm{~V}=10$, and $\mathrm{V}=7$ in the lower boundary of the formulae represent the number of variables in each proxy. $\mathcal{E}$ is the error term. 
Figure - 2: Comparison of Deposit money banks' assets and Liquid liabilities to GDP\% in all target countries

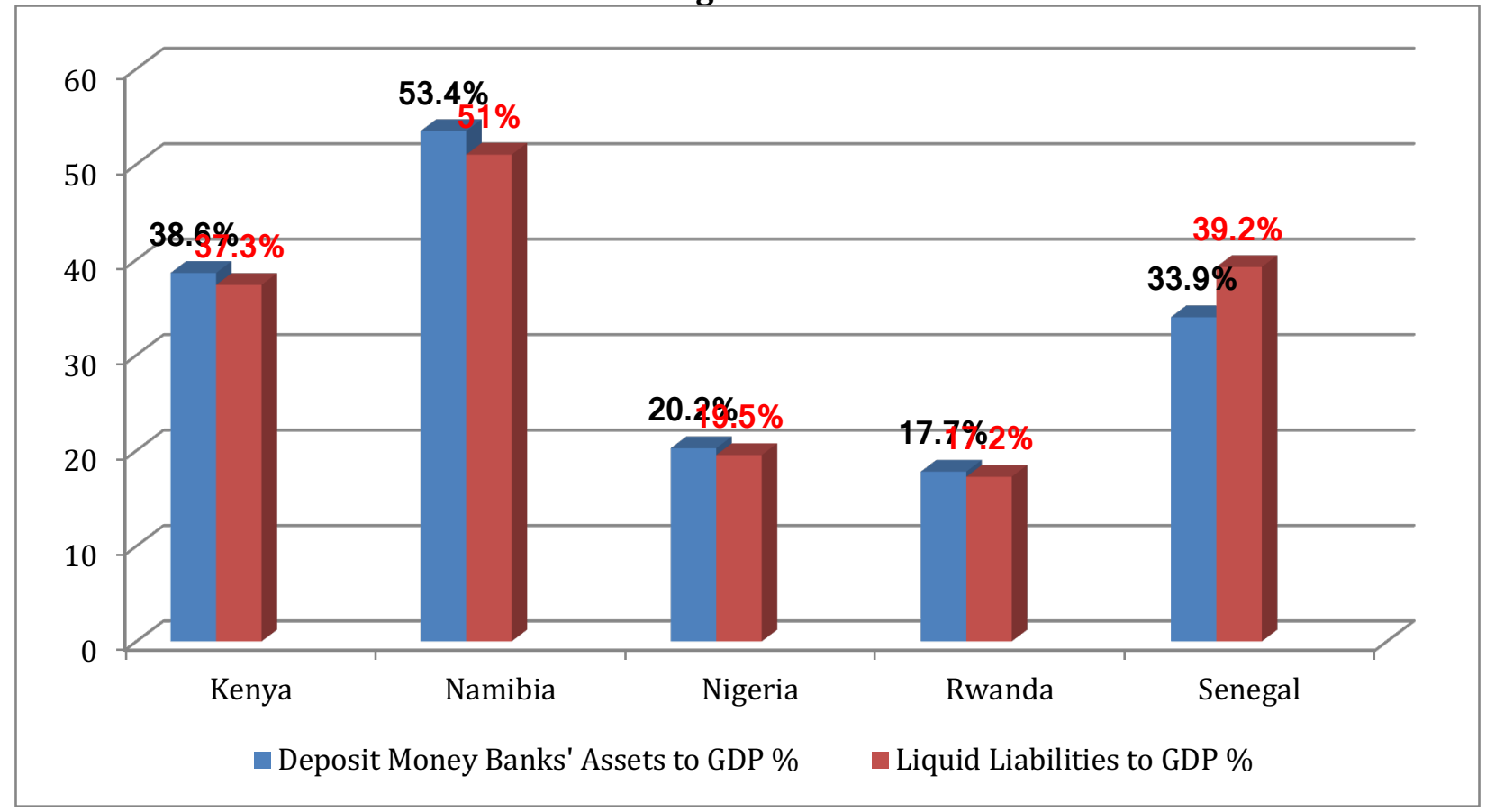

The above figure 2, reveals that when Deposit money banks' assets to GDP\% increases, the Liquid liabilities to GDP\% also increases except Senegal in which its Liquid liabilities to GDP\% is higher than its Deposit money banks' assets to GDP\%.

Figure - 3: Comparison of Bank net interest margin (\%), Bank cost to income ratio (\%), and Return on equity after tax (\%) in all target countries

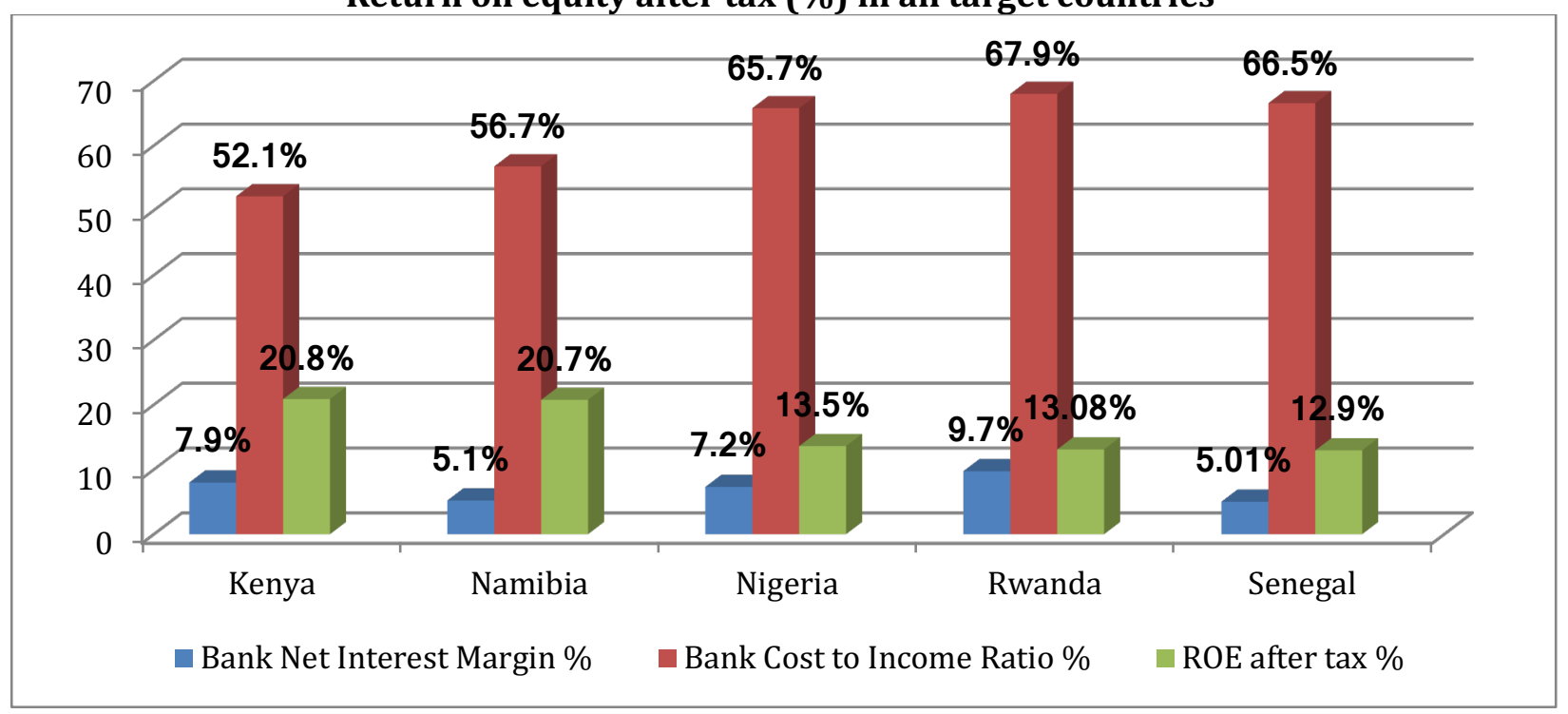

The above figure 3 shows that both Bank net interest margin (\%) and Return on equity after tax (\%) are very low compared to Bank cost to income ratio (\%) in all five target countries. 
Figure - 4: Comparison of Bank lending deposit spread and Bank nonperforming loans to gross loans (\%) in all target countries

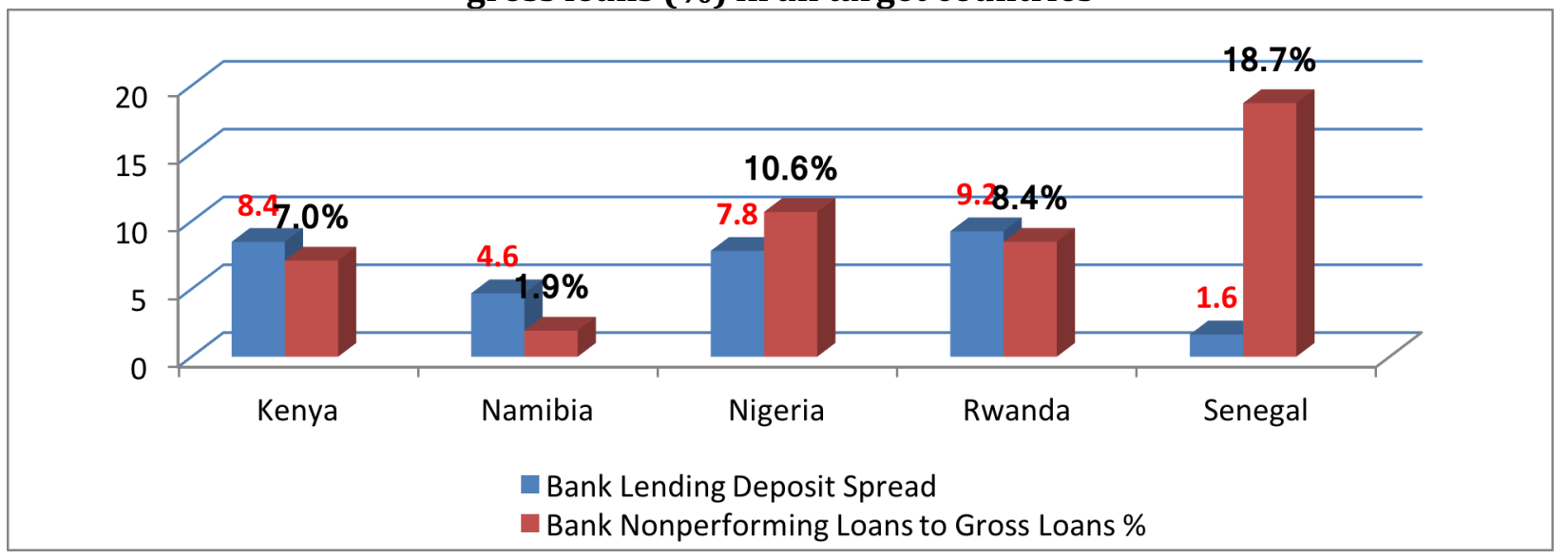

Figure 4 above is a combination of financial efficiency and stability. In the case of Senegal, it is well known to finance; when deposit rate (DR) decreases, nonperforming loans increase. The case of Namibia is exceptional; its DR is much lower than other rates of Kenya, Nigeria, and Rwanda. Namibia also has a lower rate of nonperforming loans to gross loans (\%).

Figure - 5: Comparison of provisions to nonperforming loans in all target countries

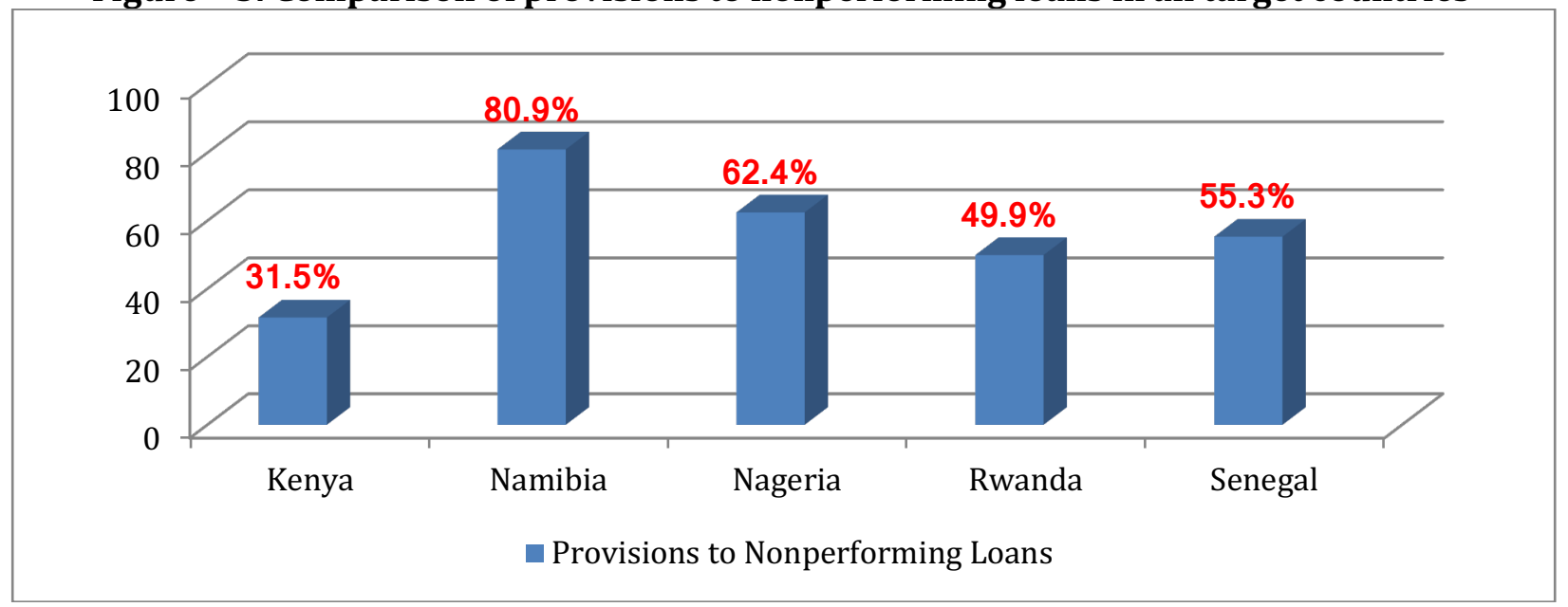

Figure 5 reveals that Sub-Saharan African countries adopted loan covering policy. For the countries in the study, Namibia leads covering nonperforming loans policy in $\mathbf{8 0 \%}$ while Nigeria, Senegal, Rwanda, and Kenya cover $62 \%$-- 31\% of bad loans every year. 


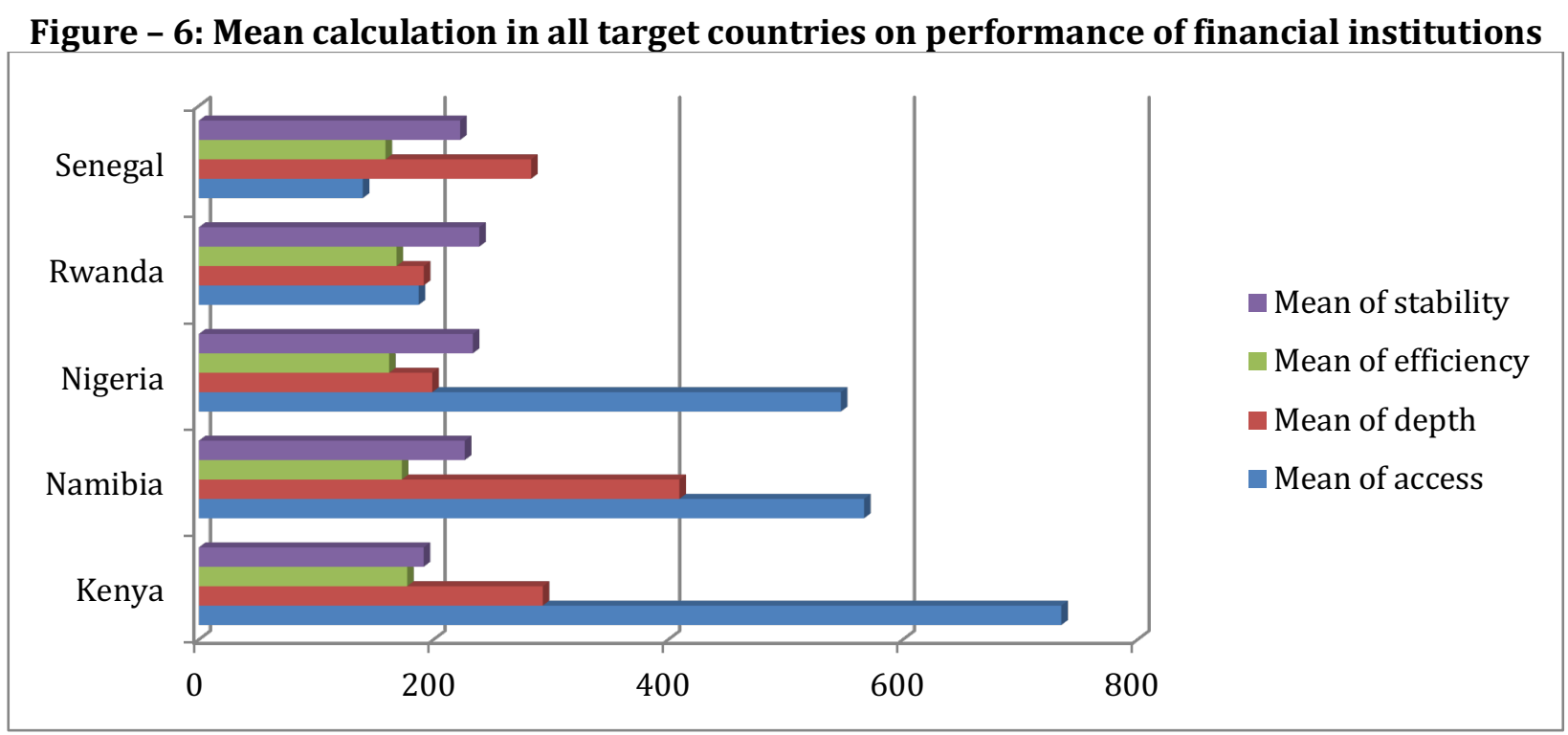

The above figure 6 is a visual aid which is practically showing the Mean results that we explained in table 4.32. In Kenyan financial institutions, access has the highest Mean average, over $\mathbf{7 0 \%}$. Mean average of financial depth accounts for $\mathbf{2 8 \%}$ while Mean average of stability explains 17\% where as efficiency has the least Mean average, 16\%. In Namibian financial institutions, access has $\mathbf{5 6 \%}$ of Mean average while financial depth scored $\mathbf{4 0 \%}$ where as stability and efficiency scores Mean averages of $\mathbf{2 1 \%}$ and $\mathbf{1 5 \%}$ respectively. The Mean average of access in Nigerian financial institutions is $\mathbf{5 4 \%}$ while stability shows $\mathbf{2 2 \%}$ of Mean average where as depth and efficiency scored Mean averages of $\mathbf{1 8 \%}$ and $\mathbf{1 3 \%}$ respectively. Rwandan financial institutions displayed 23\% of Mean average in stability, while financial depth, access and efficiency revealed Mean averages of $17 \%, 16 \%$, and $14 \%$ respectively. In Senegal, financial institutions account for low Mean averages; 27\% in financial depth, 21\% in stability, $\mathbf{1 3} \%$ in efficiency, and $\mathbf{1 3 \%}$ in financial access.

Figure - 7: Comparison of target countries in mean calculation of all four proxies on performance of financial institutions

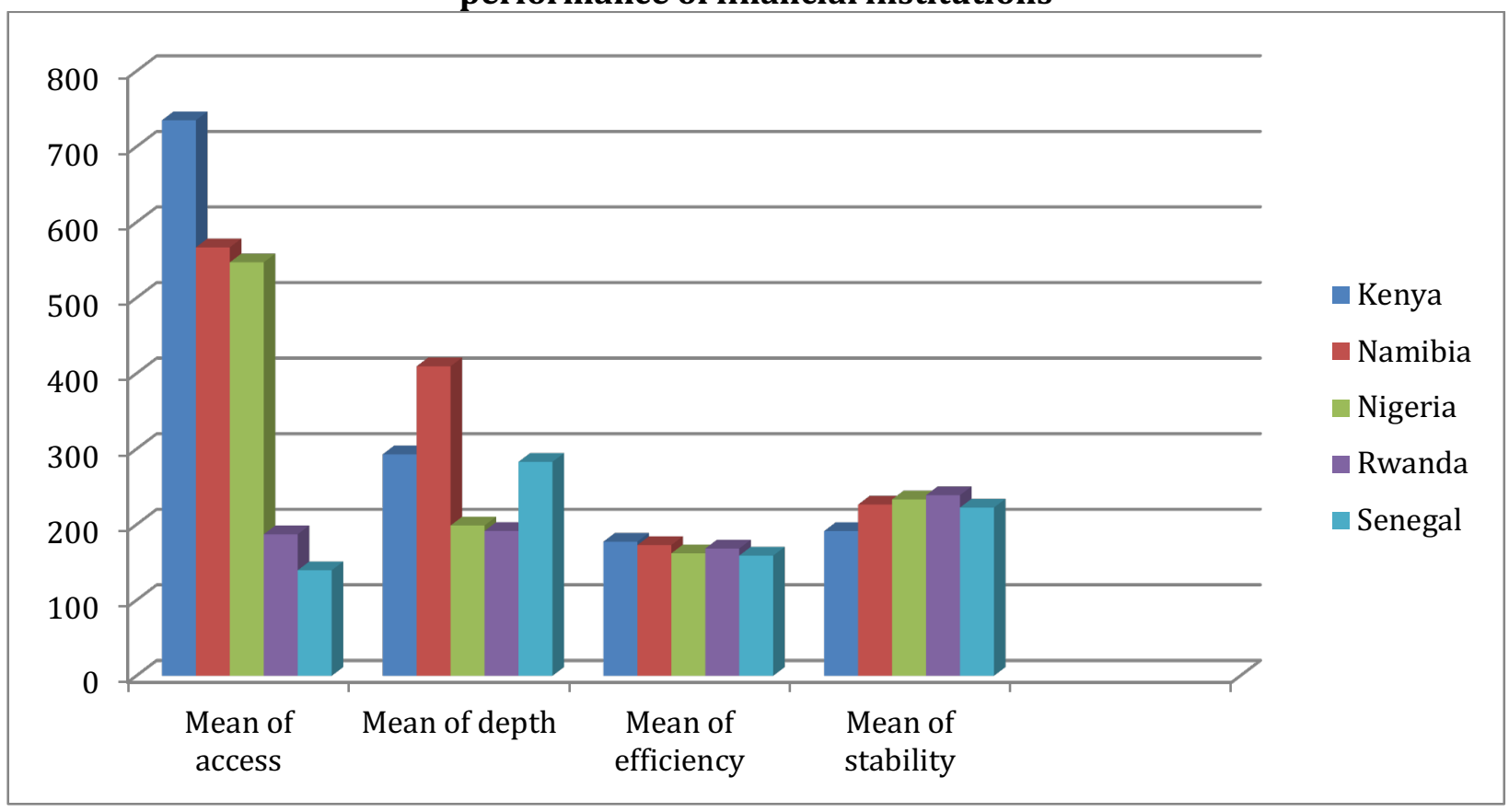


This visual aid, figure $\mathbf{7}$ is showing comparison of five target countries in Mean calculation of all four proxies. In financial access Kenya has a leading role above $\mathbf{7 0 \%}$ Mean average over other countries while Namibia and Nigeria scores $\mathbf{5 6 \%}$ and $\mathbf{5 4 \%}$ of Mean average where as Rwanda and Senegal revealed $16 \%$ and $13 \%$ of Mean average in access respectively. In financial depth, Namibia has the largest Mean average $\mathbf{4 0 \%}$ while Kenya and Senegal scored $\mathbf{2 8 \%}$ and $\mathbf{2 7 \%}$ respectively where as Nigeria and Rwanda have the least Mean averages of financial depth, $\mathbf{1 8 \%}$ and $\mathbf{1 7 \%}$ respectively. In financial efficiency, Kenya and Namibia revealed $16 \%$ and $15 \%$ of Mean averages respectively while Rwanda leveled $14 \%$ of Mean average where as Nigeria and Senegal revealed the same result of Mean averages in efficiency, 13\%. In financial stability, Rwanda presents $23 \%$ of Mean average while Nigeria ranks the second position, $\mathbf{2 2 \%}$ of Mean averages where as Namibia and Senegal revealed the same result of Mean average, $\mathbf{2 1 \%}$. Kenya ranks the fifth position in Mean average of financial stability, 17\%.

Table - 1: Mean calculation of all five target countries on performance of financial institutions

\begin{tabular}{lccccc}
\hline $\begin{array}{l}\text { Target } \\
\text { countries }\end{array}$ & Mean of access & Mean of depth & $\begin{array}{c}\text { Mean of } \\
\text { efficiency }\end{array}$ & $\begin{array}{c}\text { Mean of } \\
\text { stability }\end{array}$ & Overall mean \\
\hline Kenya & 735.0084 & 293.0530 & 177.5122 & 191.5205 & $1,397.0941$ \\
Namibia & 566.8851 & 409.5121 & 172.9537 & 226.5948 & $1,375.9457$ \\
Nigeria & 547.0927 & 198.8945 & 162.0585 & 233.4028 & $1,141.4485$ \\
Rwanda & 187.3008 & 191.6646 & 168.4126 & 238.9574 & 786.3354 \\
Senegal & 139.6671 & 283.1240 & 159.0546 & 222.6401 & 804.4858 \\
\hline
\end{tabular}

As seen from above table 1, in Kenya, Namibia and Nigeria, the result of Mean calculation of financial access is greater than other accounts of depth, efficiency and stability. Kenya accounts for (735.0084), while Namibia (566.8851) and Nigeria (547.0927) ranks second and third position of Mean result respectively. Rwanda (187.3008) and Senegal (139.6671) comes fourth and fifth rank of Mean result in financial access for the last 10 years from 2007 - 2016. The result of Mean of financial depth and financial stability is mixed in country wise. In Kenya, Namibia and Senegal, their Mean result of financial depth is greater than their Mean result of efficiency and stability, while Nigeria and Rwanda, their Mean result of financial depth is greater than their Mean result of efficiency but less than the Mean result of their financial stability. Namibia (409.1240) ranks the first position in Mean calculation of financial depth while Kenya (293.0530) and Senegal (283.1240) ranks the second and third position respectively. Nigeria (198.8945) and Rwanda (191.6646) comes the fourth and fifth position respectively. The Mean calculation of financial stability in rank wise is as follows: Rwanda (238.9574); Nigeria (233.4028); Namibia (226.5948); Senegal (222.6401); and Kenya (191.5205). Financial efficiency has the least Mean results of all four proxies and it is as follows in rank wise: Kenya (177.5122); Namibia (172.9537); Rwanda (168.4126); Nigerian (162.0585); and Senegal (159. 0546). The overall performance of all four proxies of rank wise in Mean calculation is as follows: Kenya (1,397.0941); Namibia (1,375.9457); Nigeria (1,141.4485); Senegal (804.4858); and Rwanda (786.3354). 


\section{(1) Kenya}

Table - 2: Coefficients (a, b) for performance of financial access in Kenyan financial institutions

\begin{tabular}{|c|c|c|c|c|c|c|}
\hline \multirow{2}{*}{\multicolumn{2}{|c|}{ Model }} & \multicolumn{2}{|c|}{ Un-standardized Coefficients } & \multirow{2}{*}{$\begin{array}{c}\begin{array}{c}\text { Standardized } \\
\text { Coefficients }\end{array} \\
\text { Beta }\end{array}$} & \multirow[b]{2}{*}{$\mathrm{t}$} & \multirow[b]{2}{*}{ P-value } \\
\hline & & B & Std. Error & & & \\
\hline \multirow[t]{2}{*}{1} & (Constant) & 1.540 & .494 & & 3.118 & .014 \\
\hline & ATMs per 100,000 adults & .404 & .054 & .936 & 7.502 & .000 \\
\hline
\end{tabular}

a. Dependent Variable: Bank branches per 100,000 adults

b. Weighted Least Squares Regression - Weighted by Bank accounts per 1,000 adults

From the above table 2, the independent variable (ATMs per 100,000 adults) $(\mathbf{t}=\mathbf{7 . 5 0 2}$ ) of financial access improves the performance of Kenyan financial institutions. It is concluded that the independent variable of access is useful to identify the direction of financial institutions.

Table -3: Coefficients $(a, b)$ for performance of financial depth in Kenyan financial institutions

\begin{tabular}{|c|c|c|c|c|c|c|}
\hline \multirow{2}{*}{\multicolumn{2}{|c|}{ Model }} & \multicolumn{2}{|c|}{ Un-standardized Coefficients } & \multirow{2}{*}{$\begin{array}{c}\begin{array}{c}\text { Standardized } \\
\text { Coefficients }\end{array} \\
\text { Beta }\end{array}$} & \multirow[b]{2}{*}{$\mathrm{t}$} & \multirow[b]{2}{*}{ P-value } \\
\hline & & $\mathrm{B}$ & Std. Error & & & \\
\hline \multirow[t]{2}{*}{1} & (Constant) & 102.344 & 4.907 & & 20.857 & .000 \\
\hline & $\begin{array}{l}\text { Deposit money banks' assets } \\
\text { to GDP (\%) }\end{array}$ & 2.972 & .125 & .993 & 23.740 & .000 \\
\hline
\end{tabular}

a. Dependent Variable: Cluster 1

b. Weighted Least Squares Regression - Weighted by Liquid liabilities to GDP (\%)

From above table 3, it is found that the independent variable of financial depth (deposit money banks' assets to GDP (\%)) ( $\mathbf{t = 2 3 . 7 4 0 )}$ drives the performance of Kenyan financial institutions to a positive direction. It is concluded that the independent variable of depth plays an important role in Kenyan financial institutions.

Table: 4: Coefficients $(a, b)$ for performance of financial efficiency in Kenyan financial institutions

\begin{tabular}{|c|c|c|c|c|c|c|}
\hline \multirow{2}{*}{\multicolumn{2}{|c|}{ Model }} & \multicolumn{2}{|c|}{ Un-standardized Coefficients } & \multirow{2}{*}{$\begin{array}{c}\begin{array}{c}\text { Standardized } \\
\text { Coefficients }\end{array} \\
\text { Beta }\end{array}$} & \multirow[b]{2}{*}{$\mathrm{t}$} & \multirow[b]{2}{*}{ P-value } \\
\hline & & $\mathrm{B}$ & Std. Error & & & \\
\hline \multirow[t]{2}{*}{1} & (Constant) & 81.119 & 33.200 & & 2.443 & .040 \\
\hline & Bank net interest margin (\%) & 4.598 & 4.144 & .365 & 1.110 & .299 \\
\hline
\end{tabular}

a. Dependent Variable: Cluster 2

b. Weighted Least Squares Regression - Weighted by Bank cost to income ratio (\%)

As it is seen from above table $\mathbf{4}$, the statistical test $(\mathbf{t = 1 . 1 1 0})$ of financial efficiency is insignificant. 
Table - 5: Coefficients (a, b) for performance of financial stability in Kenyan financial institutions

\begin{tabular}{|c|c|c|c|c|c|c|}
\hline \multirow{2}{*}{\multicolumn{2}{|c|}{ Model }} & \multicolumn{2}{|c|}{ Un-standardized Coefficients } & \multirow{2}{*}{$\frac{\begin{array}{c}\text { Standardized } \\
\text { Coefficients }\end{array}}{\text { Beta }}$} & \multirow[b]{2}{*}{$\mathrm{t}$} & \multirow[b]{2}{*}{ P-value } \\
\hline & & $\mathrm{B}$ & Std. Error & & & \\
\hline \multirow[t]{2}{*}{1} & (Constant) & 150.879 & 13.067 & & 11.546 & .000 \\
\hline & Bank Z-score & -.386 & .700 & -.191 & -.551 & .597 \\
\hline
\end{tabular}

a. Dependent Variable: Cluster 3

b. Weighted Least Squares Regression - Weighted by Provisions to nonperforming loans (\%)

As found from above table $\mathbf{5}$, the statistical test $(\mathrm{t}=\mathbf{- . 5 5 1})$ of financial stability is insignificant. $\mathbf{Y}=\sum \mathbf{X}_{1}\left(\mathbf{B}_{1}\right)+\mathbf{X}_{2}\left(\mathbf{B}_{2}\right)+\mathbf{X}_{3}\left(\mathbf{B}_{3}\right)+\mathbf{X}_{4}\left(\mathbf{B}_{4}\right)+\varepsilon$

$\mathrm{Y}=(\mathbf{7 3 5 . 0 0 8 4} * \mathbf{0 . 4 0 4})+(293.0530 * 2.973)+(177.5122 * 4.598)+(191.5205 *-.386)+\varepsilon=$ $1,910.4$

Overall central tendency mean $=1,397.09$

Model outcome $(1,910.4)>$ Mean average $(1,397.09)=(1,910.4-1,397.09)=513.31$ is recognized as error calculation of performance in Kenyan financial institutions.

\section{(2) Namibia}

Table - 6: Coefficients $(a, b)$ for performance of financial access in Namibian financial institutions

\begin{tabular}{|c|c|c|c|c|c|c|}
\hline \multirow{2}{*}{\multicolumn{2}{|c|}{ Model }} & \multicolumn{2}{|c|}{ Un-standardized Coefficients } & \multirow{2}{*}{$\begin{array}{c}\begin{array}{c}\text { Standardized } \\
\text { Coefficients }\end{array} \\
\text { Beta }\end{array}$} & \multirow[b]{2}{*}{$\mathrm{t}$} & \multirow[b]{2}{*}{ P-value } \\
\hline & & $\mathrm{B}$ & Std. Error & & & \\
\hline \multirow[t]{2}{*}{1} & (Constant) & 10.616 & 1.047 & & 10.141 & .000 \\
\hline & ATMs per 100,000 adults & .048 & .020 & .651 & 2.428 & .041 \\
\hline
\end{tabular}

a. Dependent Variable: Bank branches per 100,000 adults

b. Weighted Least Squares Regression - Weighted by Bank accounts per 1,000 adults

From above table of $\mathbf{6}$, it is understood that independent variable of financial access (ATMs per 100,000 adults) $(\mathbf{t}=\mathbf{2 . 4 2 8})$ improves the performance of Namibian financial institutions. It is concluded if Namibian financial institutions increase the number of ATMs per 100,000 adults; this will increase the performance of financial access which will finally become a key independent variable to identify the right direction of Namibian financial institutions.

Table - 7: Coefficients $(a, b)$ for performance of financial depth in Namibian financial institutions

\begin{tabular}{|c|c|c|c|c|c|c|}
\hline \multirow{2}{*}{\multicolumn{2}{|c|}{ Model }} & \multicolumn{2}{|c|}{ Un-standardized Coefficients } & \multirow{2}{*}{$\begin{array}{c}\text { Standardized } \\
\text { Coefficients }\end{array}$} & \multirow[b]{2}{*}{$\mathrm{t}$} & \multirow[b]{2}{*}{ P-value } \\
\hline & & $\mathrm{B}$ & Std. Error & & & \\
\hline \multirow[t]{2}{*}{1} & (Constant) & 73.660 & 50.271 & & 1.465 & .181 \\
\hline & $\begin{array}{l}\text { Deposit money banks' assets } \\
\text { to GDP (\%) }\end{array}$ & 4.345 & .940 & .853 & 4.621 & .002 \\
\hline
\end{tabular}

a. Dependent Variable: Cluster 1

b. Weighted Least Squares Regression - Weighted by Liquid liabilities to GDP (\%) 
From the above table 7, It is understood that independent variable of deposit money banks' assets to GDP (\%) ( $\mathbf{t}=\mathbf{4 . 6 2 1})$ is important for the deepening of Namibian financial institutions. It is concluded that deposit accepting institutions especially commercial banks and other financial intermediaries have opportunities to allocate society's savings for profitable investments.

Table - 8: Coefficients $(a, b)$ for performance of financial efficiency in Namibian financial institutions

\begin{tabular}{|c|c|c|c|c|c|c|}
\hline \multirow{2}{*}{\multicolumn{2}{|c|}{ Model }} & \multicolumn{2}{|c|}{ Un-standardized Coefficients } & \multirow{2}{*}{$\begin{array}{c}\begin{array}{c}\text { Standardized } \\
\text { Coefficients }\end{array} \\
\text { Beta }\end{array}$} & \multirow[b]{2}{*}{$\mathrm{t}$} & \multirow[b]{2}{*}{ P-value } \\
\hline & & $\mathrm{B}$ & Std. Error & & & \\
\hline \multirow[t]{2}{*}{1} & (Constant) & 59.654 & 35.059 & & 1.702 & .127 \\
\hline & Bank net interest margin (\%) & 9.831 & 6.713 & .460 & 1.464 & .181 \\
\hline
\end{tabular}

a. Dependent Variable: Cluster 2

b. Weighted Least Squares Regression - Weighted by Bank cost to income ratio (\%)

The above table $\mathbf{8}$, it clearly reveals that the statistical test $(\mathbf{t}=\mathbf{1 . 4 6 4})$ of financial efficiency is insignificant.

Table - 9: Coefficients $(a, b)$ for performance of financial stability in Namibian financial institutions

\begin{tabular}{|c|c|c|c|c|c|c|}
\hline \multirow{2}{*}{\multicolumn{2}{|c|}{ Model }} & \multicolumn{2}{|c|}{ Un-standardized Coefficients } & \multirow{2}{*}{$\begin{array}{c}\begin{array}{c}\text { Standardized } \\
\text { Coefficients }\end{array} \\
\text { Beta }\end{array}$} & \multirow[b]{2}{*}{$\mathrm{t}$} & \multirow[b]{2}{*}{ P-value } \\
\hline & & $\mathrm{B}$ & Std. Error & & & \\
\hline \multirow[t]{2}{*}{1} & (Constant) & 131.951 & 73.767 & & 1.789 & .111 \\
\hline & Bank Z-score & .111 & 8.365 & .005 & .013 & .990 \\
\hline
\end{tabular}

a. Dependent Variable: cluster 3

b. Weighted Least Squares Regression - Weighted by Provisions to nonperforming loans (\%)

The above table $\mathbf{9}$, it clearly demonstrates that the statistical test $(\mathbf{t}=\mathbf{. 0 1 3})$ of financial stability is insignificant.

$\mathrm{Y}=\sum \mathrm{X}_{1}\left(\mathrm{~B}_{1}\right)+\mathrm{X}_{2}\left(\mathrm{~B}_{2}\right)+\mathrm{X}_{3}\left(\mathrm{~B}_{3}\right)+\mathrm{X}_{4}\left(\mathrm{~B}_{4}\right)+\varepsilon$

$Y=(566.8851 * .048)+(409.5121 * 4.345)+(172.9537 * 9.831)+(226.5948 * 111)+\varepsilon=$ 3,532

Overall central tendency mean $=1,375.95$

Model outcome $(3,531)>$ mean average $(1,375.95)=(3,532-1,375.95)=2,155.05$ is recognized as an error calculation on performance of Namibian financial institutions. 


\section{(3) Nigeria}

Table - 10: Coefficients $(a, b)$ for performance of financial access in Nigerian financial institutions

\begin{tabular}{|c|c|c|c|c|c|c|}
\hline \multirow{2}{*}{\multicolumn{2}{|c|}{ Model }} & \multicolumn{2}{|c|}{ Un-standardized Coefficients } & \multirow{2}{*}{$\begin{array}{c}\begin{array}{c}\text { Standardized } \\
\text { Coefficients }\end{array} \\
\text { Beta }\end{array}$} & \multirow[b]{2}{*}{$\mathrm{t}$} & \multirow[b]{2}{*}{ P-value } \\
\hline & & B & Std. Error & & & \\
\hline & (Constant) & 6.569 & .617 & & 10.646 & .000 \\
\hline & ATMs per 100,000 adults & -.055 & .046 & -.387 & -1.185 & .270 \\
\hline
\end{tabular}

a. Dependent Variable: Bank branches per 100,000 adults

b. Weighted Least Squares Regression - Weighted by Bank accounts per 1,000 adults

From the coefficient table $\mathbf{1 0}$ above, it is found that the statistical test $(\mathbf{t = - 1 . 1 8 5 )}$ is insignificant.

Table - 11: Coefficients $(a, b)$ for performance of financial depth in Nigerian financial institutions

\begin{tabular}{|c|c|c|c|c|c|c|}
\hline \multirow{2}{*}{\multicolumn{2}{|c|}{ Model }} & \multicolumn{2}{|c|}{ Un-standardized Coefficients } & \multirow{2}{*}{$\begin{array}{c}\text { Standardized } \\
\text { Coefficients }\end{array}$} & \multirow[b]{2}{*}{$\mathrm{t}$} & \multirow[b]{2}{*}{ P-value } \\
\hline & & $\mathrm{B}$ & Std. Error & & & \\
\hline \multirow[t]{2}{*}{1} & (Constant) & 33.238 & 22.491 & & 1.478 & .178 \\
\hline & $\begin{array}{l}\text { Deposit money banks' assets } \\
\text { to GDP (\%) }\end{array}$ & 6.206 & 1.097 & .894 & 5.658 & .000 \\
\hline
\end{tabular}

a. Dependent Variable: Cluster 1

b. Weighted Least Squares Regression - Weighted by Liquid liabilities to GDP (\%)

From the above table 11, it is understood that the independent variable (deposit money banks' assets to GDP (\%)) (t= 5.658) increases the performance of Nigerian financial institutions. It is concluded that the independent variable of financial depth plays a major role in deepening the Nigerian financial institutions.

Table - 12: Coefficients $(a, b)$ for performance of financial efficiency in Nigerian financial institutions

\begin{tabular}{|c|c|c|c|c|c|c|}
\hline \multirow{2}{*}{\multicolumn{2}{|c|}{ Model }} & \multicolumn{2}{|c|}{ Un-standardized Coefficients } & \multirow{2}{*}{$\begin{array}{c}\begin{array}{c}\text { Standardized } \\
\text { Coefficients }\end{array} \\
\text { Beta }\end{array}$} & \multirow[b]{2}{*}{$\mathrm{t}$} & \multirow[b]{2}{*}{ P-value } \\
\hline & & $\mathrm{B}$ & Std. Error & & & \\
\hline \multirow[t]{2}{*}{1} & (Constant) & 101.689 & 38.887 & & 2.615 & .031 \\
\hline & Bank net interest margin (\%) & -1.732 & 5.292 & -.115 & -.327 & .752 \\
\hline
\end{tabular}

a. Dependent Variable: Cluster 2

b. Weighted Least Squares Regression - Weighted by Bank cost to income ratio (\%)

As per the above table 12 , the statistical test $(t=-.327)$ of financial efficiency is insignificant. 
Table - 13: Coefficients $(a, b)$ for performance of financial stability in Nigerian financial institutions

\begin{tabular}{|c|c|c|c|c|c|c|}
\hline \multirow{2}{*}{\multicolumn{2}{|c|}{ Model }} & \multicolumn{2}{|c|}{ Un-standardized Coefficients } & \multirow{2}{*}{$\begin{array}{c}\begin{array}{c}\text { Standardized } \\
\text { Coefficients }\end{array} \\
\text { Beta }\end{array}$} & \multirow[b]{2}{*}{$\mathrm{t}$} & \multirow[b]{2}{*}{ P-value } \\
\hline & & B & Std. Error & & & \\
\hline \multirow[t]{2}{*}{1} & (Constant) & 29.568 & 65.285 & & .453 & .663 \\
\hline & Bank Z-score & 7.423 & 3.914 & .557 & 1.897 & .094 \\
\hline
\end{tabular}

a. Dependent Variable: Cluster 3

b. Weighted Least Squares Regression - Weighted by Provisions to nonperforming loans (\%)

The above table 13 clearly reveals that the $t$-value $(t=1.897)$ of financial stability is insignificant.

$Y=\sum X_{1}\left(B_{1}\right)+X_{2}\left(B_{2}\right)+X_{3}\left(B_{3}\right)+X_{4}\left(B_{4}\right)+\varepsilon$

$Y=(547 *-.055)+(198.8945 * 6.206)+(162 *-1.732)+(233.4028 * 7.423)+\varepsilon=2,656.2$

\section{Overall central tendency mean $=1,141.45$}

Model outcome $(2,656.2)>$ Mean average $(1141.45)=(2,656.2-1141.45)=1,514.75$ is recognized as error calculation on performance of Nigerian financial institutions.

\section{(4) Rwanda}

Table - 14: Coefficients $(a, b)$ for performance of financial access in Rwandan financial institutions

\begin{tabular}{|c|c|c|c|c|c|c|}
\hline \multirow{2}{*}{\multicolumn{2}{|c|}{ Model }} & \multicolumn{2}{|c|}{ Un-standardized Coefficients } & \multirow{2}{*}{$\begin{array}{c}\begin{array}{c}\text { Standardized } \\
\text { Coefficients }\end{array} \\
\text { Beta }\end{array}$} & \multirow[b]{2}{*}{$\mathrm{t}$} & \multirow[b]{2}{*}{ P-value } \\
\hline & & $\mathrm{B}$ & Std. Error & & & \\
\hline \multirow[t]{2}{*}{1} & (Constant) & 4.434 & .280 & & 15.823 & .000 \\
\hline & ATMs per 100,000 adults & .291 & .071 & .821 & 4.073 & .004 \\
\hline
\end{tabular}

a. Dependent Variable: Bank branches per 100,000 adults

b. Weighted Least Squares Regression - Weighted by Bank accounts per 1,000 adults

From the above coefficient table 14, it is found that the independent variable (ATMs per 100,000 adults) ( $\mathbf{t}=\mathbf{4 . 0 7 3}$ ) improves the performance of financial access of Rwandan financial institutions. It is concluded that increasing the population of ATMs per 100,000 adults is a crucial factor for the development of Rwandan financial sector.

Table - 15: Coefficients (a, b) for performance of financial depth in Rwandan financial institutions

\begin{tabular}{|c|c|c|c|c|c|c|}
\hline \multirow{2}{*}{\multicolumn{2}{|c|}{ Model }} & \multicolumn{2}{|c|}{ Un-standardized Coefficients } & \multirow{2}{*}{$\begin{array}{c}\text { Standardized } \\
\text { Coefficients }\end{array}$} & \multirow[b]{2}{*}{$\mathrm{t}$} & \multirow[b]{2}{*}{ P-value } \\
\hline & & $\mathrm{B}$ & Std. Error & & & \\
\hline \multirow[t]{2}{*}{1} & (Constant) & 92.786 & 3.400 & & 27.291 & .000 \\
\hline & $\begin{array}{l}\text { Deposit money banks' assets } \\
\text { to GDP (\%) }\end{array}$ & 3.589 & .181 & .990 & 19.819 & .000 \\
\hline
\end{tabular}

a. Dependent Variable: Cluster 1

b. Weighted Least Squares Regression - Weighted by Liquid liabilities to GDP (\%) 
As observed from the above table 15, it clearly reveals that independent variable of financial depth (deposit money bank assets to GDP (\%)) $(\mathbf{t}=\mathbf{1 9 . 8 1 9})$ is mainly responsible the deepening of Rwandan financial institutions. It is concluded that Rwandan financial intermediaries can allocate their society's savings into profitable investments by using deposits from the public.

Table - 16: Coefficients $(a, b)$ for performance of financial efficiency in Rwandan financial institutions

\begin{tabular}{|c|c|c|c|c|c|c|}
\hline \multirow{2}{*}{\multicolumn{2}{|c|}{ Model }} & \multicolumn{2}{|c|}{ Un-standardized Coefficients } & \multirow{2}{*}{$\begin{array}{c}\begin{array}{c}\text { Standardized } \\
\text { Coefficients }\end{array} \\
\text { Beta }\end{array}$} & \multirow[b]{2}{*}{$\mathrm{t}$} & \multirow[b]{2}{*}{ P-value } \\
\hline & & $\mathrm{B}$ & Std. Error & & & \\
\hline \multirow[t]{2}{*}{1} & (Constant) & 39.700 & 45.166 & & .879 & .405 \\
\hline & Bank net interest margin (\%) & 5.237 & 4.635 & .371 & 1.130 & .291 \\
\hline
\end{tabular}

a. Dependent Variable: Cluster 2

b. Weighted Least Squares Regression - Weighted by Bank cost to income ratio (\%)

As observed from the above table 16, it is evident that the statistical test $(\mathbf{t}=\mathbf{1 . 1 3 0})$ of independent variable is insignificant.

Table - 17: Coefficients $(a, b)$ for performance of financial stability in Rwandan financial institutions

\begin{tabular}{|c|c|c|c|c|c|c|}
\hline \multirow{2}{*}{\multicolumn{2}{|c|}{ Model }} & \multicolumn{2}{|c|}{ Un-standardized Coefficients } & \multirow{2}{*}{$\begin{array}{c}\begin{array}{c}\text { Standardized } \\
\text { Coefficients }\end{array} \\
\text { Beta }\end{array}$} & \multirow[b]{2}{*}{$\mathrm{t}$} & \multirow[b]{2}{*}{ P-value } \\
\hline & & $\mathrm{B}$ & Std. Error & & & \\
\hline \multirow[t]{2}{*}{1} & (Constant) & 143.904 & 13.134 & & 10.956 & .000 \\
\hline & Bank Z-score & 4.250 & 1.570 & .691 & 2.707 & .027 \\
\hline
\end{tabular}

a. Dependent Variable: Cluster 3

b. Weighted Least Squares Regression - Weighted by Provisions to nonperforming loans (\%)

As seen from the above table $\mathbf{1 7}$, it clearly reveals that the independent variable $(\mathbf{t}=\mathbf{2 . 7 0 7})$ paves the way of the stability of financial institutions. It is concluded that bank Z-score travelled the best distance over the mean average of Rwandan financial sector.

$Y=\sum X_{1}\left(B_{1}\right)+X_{2}\left(B_{2}\right)+X_{3}\left(B_{3}\right)+X_{4}\left(B_{4}\right)+\varepsilon$

$Y=(187.3 * .291)+(191.6 * 3.589)+(168.4 * 5.237)+(238.9 * 4.250)+\varepsilon=2,639.3$

\section{Overall central tendency mean $=786.34$}

Model outcome $(2,639.3)>$ mean average $(786.34)=(2,639.3-786.34)=1,852.96$ is recognized as error calculation on performance of Rwandan financial institutions. 


\section{(5) Senegal}

Table - 18: Coefficients $(a, b)$ for performance of financial access in Senegalese financial institutions

\begin{tabular}{|c|c|c|c|c|c|c|}
\hline \multirow{2}{*}{\multicolumn{2}{|c|}{ Model }} & \multicolumn{2}{|c|}{ Un-standardized Coefficients } & \multirow{2}{*}{$\begin{array}{c}\begin{array}{c}\text { Standardized } \\
\text { Coefficients }\end{array} \\
\text { Beta }\end{array}$} & \multirow[b]{2}{*}{$\mathrm{t}$} & \multirow[b]{2}{*}{ P-value } \\
\hline & & $\mathrm{B}$ & Std. Error & & & \\
\hline \multirow[t]{2}{*}{1} & (Constant) & .660 & .641 & & 1.029 & .334 \\
\hline & ATMs per 100,000 adults & .800 & .136 & .902 & 5.899 & .000 \\
\hline
\end{tabular}

a. Dependent Variable: Bank branches per 100,000 adults

b. Weighted Least Squares Regression - Weighted by Bank accounts per 1,000 adults

As inferred from the above table 18, it clearly reveals that independent variable $\quad(\mathbf{t}=\mathbf{5 . 8 9 9})$ improves the performance of access of Senegalese financial institutions. It is concluded if Senegalese financial sector increases the population of ATMs per 100,000 adults, then development of financial access of financial institutions will be on certain.

Table - 19: Coefficients $(a, b)$ for performance of financial depth in Senegalese financial institutions

\begin{tabular}{|c|c|c|c|c|c|c|}
\hline \multirow{2}{*}{\multicolumn{2}{|c|}{ Model }} & \multicolumn{2}{|c|}{ Un-standardized Coefficients } & \multirow{2}{*}{$\begin{array}{c}\begin{array}{c}\text { Standardized } \\
\text { Coefficients }\end{array} \\
\text { Beta }\end{array}$} & \multirow[b]{2}{*}{$\mathrm{t}$} & \multirow[b]{2}{*}{ P-value } \\
\hline & & $\mathrm{B}$ & Std. Error & & & \\
\hline \multirow[t]{2}{*}{1} & (Constant) & 100.858 & 4.198 & & 24.023 & .000 \\
\hline & $\begin{array}{l}\text { Deposit money banks' assets } \\
\text { to GDP (\%) }\end{array}$ & 3.210 & .120 & .994 & 26.744 & .000 \\
\hline
\end{tabular}

a. Dependent Variable: Cluster 1

b. Weighted Least Squares Regression - Weighted by Liquid liabilities to GDP (\%)

From the above table 19, it clearly reveals that the statistical test of independent variable $(\mathbf{t}=$ 26.744) increases the performance of Senegalese financial institutions. It is concluded that the deposit money banks' assets variable of financial depth is useful for the development of Senegalese financial sector.

Table - 20: Coefficients $(a, b)$ for performance of financial efficiency in Senegalese financial institutions

\begin{tabular}{|c|c|c|c|c|c|c|}
\hline \multirow{2}{*}{\multicolumn{2}{|c|}{ Model }} & \multicolumn{2}{|c|}{ Un-standardized Coefficients } & \multirow{2}{*}{$\begin{array}{c}\begin{array}{c}\text { Standardized } \\
\text { Coefficients }\end{array} \\
\text { Beta }\end{array}$} & \multirow[b]{2}{*}{$\mathrm{t}$} & \multirow[b]{2}{*}{ P-value } \\
\hline & & $\mathrm{B}$ & Std. Error & & & \\
\hline \multirow[t]{2}{*}{1} & (Constant) & 79.918 & 17.800 & & 4.490 & .002 \\
\hline & Bank net interest margin (\%) & 1.510 & 3.527 & .150 & .428 & .680 \\
\hline
\end{tabular}

a. Dependent Variable: Cluster 2

b. Weighted Least Squares Regression - Weighted by Bank cost to income ratio (\%)

As referred from the above table 20 , the statistical test $(\mathbf{t}=\mathbf{. 4 2 8})$ of independent variable in efficiency is insignificant. 
Table - 21: Coefficients $(a, b)$ for performance of financial stability in Senegalese financial institutions

\begin{tabular}{|c|c|c|c|c|c|c|}
\hline \multirow{2}{*}{\multicolumn{2}{|c|}{ Model }} & \multicolumn{2}{|c|}{ Un-standardized Coefficients } & \multirow{2}{*}{$\begin{array}{c}\begin{array}{c}\text { Standardized } \\
\text { Coefficients }\end{array} \\
\text { Beta }\end{array}$} & \multirow[b]{2}{*}{$\mathrm{t}$} & \multirow[b]{2}{*}{ P-value } \\
\hline & & $\mathrm{B}$ & Std. Error & & & \\
\hline \multirow[t]{2}{*}{1} & (Constant) & 150.131 & 9.889 & & 15.181 & .000 \\
\hline & Bank Z-score & .207 & .688 & .106 & .301 & .771 \\
\hline
\end{tabular}

a. Dependent Variable: Cluster 3

b. Weighted Least Squares Regression - Weighted by Provisions to nonperforming loans (\%)

As seen from the above table $\mathbf{2 1}$, the statistical test $(\mathbf{t}=\mathbf{. 3 0 1})$ of independent variable is insignificant.

$Y=\sum X_{1}\left(B_{1}\right)+X_{2}\left(B_{2}\right)+X_{3}\left(B_{3}\right)+X_{4}\left(B_{4}\right)+\varepsilon$

$Y=(139.6 * .800)+(283.1 * 3.210)+(159 * 1.510)+(222.6 * .207)+\varepsilon=1,306.5$

\section{Overall central tendency mean $=\mathbf{8 0 4 . 4 9}$}

Model outcome $(1,306.5)>$ mean average $(804.49)=(1,306.5-804.49)=502.01$ is recognized as error calculation on performance of Senegalese financial institutions.

Table -22: Performance of financial access in financial institutions of all target countries

\begin{tabular}{cccccc}
\hline $\begin{array}{c}\text { Target } \\
\text { countries }\end{array}$ & $\begin{array}{c}\text { R square of } \\
\text { access }\end{array}$ & F ratio & t-value & P-value & Significance \\
\hline Kenya & .876 & 56.282 & 7.502 & $.000^{\text {a }}$ & Significant \\
Namibia & .424 & 5.896 & 2.428 & $.041^{\text {a }}$ & Significant \\
Nigeria & .149 & 1.405 & -1.185 & $.2^{2} 0^{\text {a }}$ & Insignificant \\
Rwanda & .675 & 16.587 & 4.073 & $.004^{\text {a }}$ & Significant \\
Senegal & .813 & 34.802 & 5.899 & $.000^{\text {a }}$ & Significant \\
\hline
\end{tabular}

Table-23: Performance of financial depth in financial institutions of all target countries

\begin{tabular}{cccccc}
\hline $\begin{array}{c}\text { Target } \\
\text { countries }\end{array}$ & $\begin{array}{c}\text { R square of } \\
\text { depth }\end{array}$ & F ratio & t-value & P-value & Significance \\
\hline Kenya & .986 & 563.590 & 23.740 & $.000^{\text {a }}$ & Significant \\
Namibia & .727 & 21.352 & 4.621 & $.002^{\text {a }}$ & Significant \\
Nigeria & .800 & 32.009 & 5.658 & $.000^{\text {a }}$ & Significant \\
Rwanda & .980 & 392.812 & 19.819 & $.000^{\text {a }}$ & Significant \\
Senegal & .989 & 715.256 & 26.744 & $.000^{\text {a }}$ & Significant \\
\hline
\end{tabular}


Table-24: Performance of financial efficiency in financial institutions of all target countries

\begin{tabular}{cccccc}
\hline $\begin{array}{c}\text { Target } \\
\text { countries }\end{array}$ & $\begin{array}{c}\text { R square of } \\
\text { efficiency }\end{array}$ & F ratio & t-value & P-value & Significance \\
\hline Kenya & .133 & 1.231 & 1.110 & $.299^{a}$ & Insignificant \\
Namibia & .211 & 2.144 & 1.464 & $.181^{\text {a }}$ & Insignificant \\
Nigeria & .013 & .107 & -.327 & $.752^{\text {a }}$ & Insignificant \\
Rwanda & .138 & 1.277 & 1.130 & $.291^{\text {a }}$ & Insignificant \\
Senegal & .022 & .183 & .428 & $.680^{a}$ & Insignificant \\
\hline
\end{tabular}

Table-25: Performance of financial stability in financial institutions of all target countries

\begin{tabular}{cccccc}
\hline $\begin{array}{c}\text { Target } \\
\text { countries }\end{array}$ & $\begin{array}{c}\text { R square of } \\
\text { stability }\end{array}$ & F ratio & t-value & P-value & Significance \\
\hline Kenya & .037 & .303 & -.551 & $.597^{\text {a }}$ & Insignificant \\
Namibia & .000 & .000 & .013 & $.990^{\text {a }}$ & Insignificant \\
Nigeria & .310 & 3.597 & 1.897 & $.094^{\text {a }}$ & Insignificant \\
Rwanda & .478 & 7.329 & 2.707 & $.027^{\text {a }}$ & Significant \\
Senegal & .011 & .091 & .301 & $.771^{\text {a }}$ & Insignificant \\
\hline
\end{tabular}

Table - 26: Overall performance of financial institutions in five SSA target countries

\begin{tabular}{|l|c|c|c|}
\hline \multicolumn{1}{|c|}{ Target countries } & Model outcome & Mean average & Error calculation \\
\hline Kenya & $1,910.4$ & $1,397.09$ & 513.31 \\
\hline Namibia & 3,531 & $1,375.95$ & $2,155.05$ \\
\hline Nigeria & $2,656.2$ & 1141.45 & $1,514.75$ \\
\hline Rwanda & $2,639.3$ & 786.34 & $1,852.96$ \\
\hline Senegal & $1,306.5$ & $\mathbf{8 0 4 . 4 9}$ & 502.01 \\
\hline
\end{tabular}

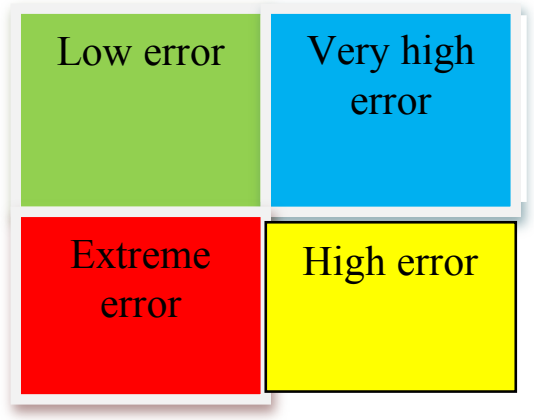

\section{DISCUSSION OF RESULTS}

As referred from above table 26, the model outcome is greater than the Mean average in all five countries. As it is seen from the table, the result of calculated error between model outcome and Mean average is mixed; Kenya and Senegal has low error while Nigeria, Rwanda, 
and Namibia, their model outcome accounts for high, very high and extreme error respectively. To explain the variation between error calculations among target countries, we looked into $\mathbf{R}$ Square, Std. Error of the Estimate and Residuals from ANOVA tables.

Namibia in which its model has extreme error, the $\mathbf{R}^{\mathbf{2}}$ of financial access is very weak (42.4\%), the standard error of the estimate is very big (14.3); at this stage we remind readers of this report that access has three variables only. The ANOVA residuals are also very big $(\mathbf{1 , 6 3 6 . 5 )}$. The $\mathbf{F}$ ratio is weak (5.896). The $\mathbf{R}$ Square of financial depth is quite strong $\mathbf{( 7 2 . 7 \% )}$ but it

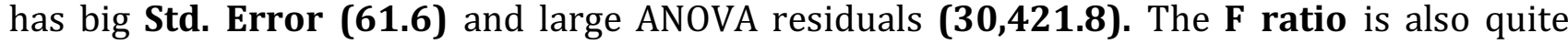
weak (21.352). The $\mathbf{R}^{\mathbf{2}}$ of efficiency is insignificant (21.1\%), its standard error of the estimate is getting bigger than before (69.2), and the ANOVA residual is also getting larger

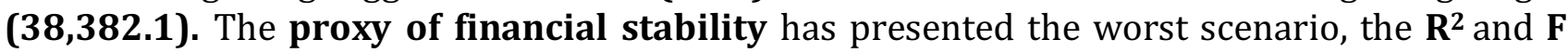
ratio is both (.000) meaning the independent variable of stability (Bank Z- score) failed to explain the dependent variables. This phenomenon caused that both standard error of the estimate and ANOVA residuals produced the biggest Std. Error of the estimate (159.2) and the largest unanalyzed data $(203,263.1)$.

Rwanda which its model has very high error, the process of error calculation explanations is the same. Rwanda has three significant proxies; financial access, depth and financial stability. But the only strong equation that financial institutions in Rwanda have is the $\mathbf{R}^{\mathbf{2}}$ $\mathbf{( 9 8 \% )}$ of financial depth. The equation of access is weak whereas $\mathbf{R}$ Square of stability is very weak. Like Namibia, the Rwandan financial institutions, the Std. Error of the Estimate of access (6.3), efficiency (79.2), and stability (43.1) is getting bigger. Also the ANOVA tables of access (319.4), depth (903.3), efficiency $(50,202.6)$, and stability $(14,877.3)$ experienced larger amount of data leftovers (residuals). The low $\mathbf{F}$ ratio of access (16.587) and stability (7.329) in Rwandan financial institutions may also explain about the very high error calculation in Rwandan financial sector.

The Nigerian financial institutions has one proxy; financial depth in significance $\left(\mathbf{R}^{\mathbf{2}}=\mathbf{8 0} \%\right)$. Like Rwanda and Namibia, financial institutions in Nigeria have bigger Std. Error of the Estimate in access (10.7), efficiency (130.09), and stability (233.6). ANOVA tables of Nigerian financial sector scored an overall residual of $(\mathbf{5 8 2 , 1 3 9 . 1 7 8})$. The data residuals of Kenyan and Senegalese financial institutions is bigger than leftover of financial sector in Rwanda but both countries; Kenya and Senegal, their financial institutions enjoy the biggest $\mathbf{F}$ ratios in financial depth $(F=\mathbf{5 6 3 . 5 9 0}),(F=\mathbf{7 1 5 . 2 5 6})$ respectively. Also the contribution of independent variable of access to dependent variables $\mathbf{8 7 . 6 \%}$ and $\mathbf{8 1 . 3 \%}$ in financial sectors of Kenya and Senegal respectively may explain the reason why their error calculation is low.

The error calculation of Senegalese and Kenyan financial institutions is normal while the financial institutions in Nigeria, their model outcome produced very high error whereas Rwanda and Namibia, their outcome accounts for very high and extremely high error respectively.

\section{CONCLUSION}

The financial sector of Sub-Sahara Africa went through massive reforms of structural adjustment policies (SAP) that started early in 1980s. SAP was implemented by the World Bank and IMF. The aim was to restructure and privatize state-owned banks. There was also liberalization policies aimed at to relieve capital controls and restrictions, enhance supervision and to frame new regulatory reforms in the banking sector. Many years later, it was proved that African financial systems benefited from SAP program. This structural adjustment led the African financial sector to become more efficient in deposit taking institutions. SAP also helped African financial institutions to channeling financial resources to more productive sectors. 
Sub-Saharan financial institutions and their services have great importance to the financial system. To developing African financial institutions and their services is inevitable. This is responding to economic growth of Sub-Saharan African countries. Sub-Saharan African states stepped into a lot of financial reforms and regulations that acted accordingly to the development of financial institutions. The today's African financial institutions are more developed than their predecessors in the past. But the question is; is today's customers better treated and better serviced?

One of the best ideas that can answer the above mentioned question is that Sub-Saharan financial institutions try to deliver further financial access especially less populated and rural areas of Sub-Sahara region. This can be considered to be a better chance that can lead the African financial institutions and their services to a better direction.

\section{References:}

Abdulai, A., \& Tewari, D. D. (2017). Determinants of Microfinance Outreach in Sub-Saharan Africa: A panel Approach. Acta Commercii - Independent Research Journal in the Management Sciences , 17 (1), 1-10.

Akande, J. O., \& Kwenda, F. (2017). Competitive Condition of Sub-Saharan Africa Commercial Banks. De Gruyter Open. Studia Universitatis Babes-Bolyai Oeconomica, 62 (2), 55-76.

Akinlo, A. E., \& Egbetunde, T. (2010). Financial Development and Economic Growth: The Experience of 10 SubSaharan African Countries Revisited. The Review of Finance and Banking , 02 (1), 017-028.

Allen, F., Carletti, E., Cull, R., Qian, J., Senbet, L., \& Valenzuela, P. (2013). Improving Access to Banking: Evidence from Kenya. World Bank. Policy Research Working Paper 6593 , 1-39.

Allen, F., Otchere, I., \& Senbet, L. W. (2011). African Financial Systems: A Review. Review of Development Finance, 79-113.

Allen, J., \& Engert, W. (2007). Efficiency and Competition in Canadian Banking. Department of Monetary and Financial Analysis. Bank of Canada Review , pp. 33-45.

Alpha, B. B., Ding, Y., Abdrahmane, K., \& Kargbo, M. (2016). A Study on the Impact of Financial Intermediation on Economic Growth: Panel Evidence from West Africa. Journal of Management Policies and Practices , 4 (1), 27-55.

Aluko, O. A., \& Ajayi, M. A. (2017). Determinants of Banking Sector Development: Evidence From Sub-Saharan African Countries. Borsa Istanbul Review , 1-18.

Amel, D., Barnes, C., Panetta, F., \& Salleo, C. (2002, August 15). Consolidation and Efficiency in the Financial Sector: A Review of the International Evidence. Federal Reserve Board, Washington, DC / Department of Finance - Ottawa, Canada / Research Department, Bank of Italy, pp. 1-52.

Anayiotos, G. C., \& Toroyan, H. (2009, November). Institutional Factors and Financial Sector Development: Evidence from Sub-Saharan Africa. IMF Working Paper, Monetary and Capital Markets Department , pp. 3-14.

Anayiotos, G., Toroyan, H., \& Vamvakidis, A. (2010). The Efficiency of Emerging Europe's Banking Sector Before and After the Recent Economic Crisis. Financial Theory and Practice, 34 (3), 247-267.

Asongu, S. A. (2017). Improving financial Access in Africa: Insights from Information Sharing and Financial Sectors Development. MPRA Munich Personal RePEc Archive , 1-9.

Ayat, T. L. (2016). The Causes of the Financial Crisis in Nile Commercial Bank in Juba, South Sudan. International Journal of Economics and Finance, 5 (3), 14-34.

Babajide, A. A., Olokoyo, F. O., \& Adegboye, F. B. (2015). Predicting Bank Failure in Nigeria Using Survival Analysis Approach. Journal of South African Business Research , 2015 (2015), 1-17. Doi: 10.5171/2015.965940.

Beck, T., \& Cull, R. (2013). Banking in Africa. CSAE Centre for the Study of African Economies. Working Paper , 1-44.

Beck, T., Demirgüç-Kunt, A., \& Honohan, P. (2008, May 15). Access to Financial Services: Measurement, Impact and Policies. The World Bank Research Observer. Doi: 10.1093/wbro/lkn008 · Source: RePEc , pp. 1-42.

Belanová, K. (2013). Comparison of Access to Finance in Visegrad Countries. 9th International Scientific Conference Financial Management of Firms and Financial Institutions (pp. 14-23). Ostrava, Czech Republic: VŠB-TU Ostrava, Faculty of Economics, Finance Department. 
Berger, A. N., \& DeYoung, R. (1997). Problem Loans and Cost Efficiency in Commercial Banks. Journal of Banking and Finance, 21, 1-30.

Brack, E., \& Jimborean, R. (2009, April). The Cost- Efficiency of French Banks. International Affairs Department, French Banking Federation / Monetary Policy Research Department, Banque de France, pp. 1-30.

Castellanos, S. G., \& Garza-García, J. G. (2013). Competition and Efficiency in the Mexican Banking Sector. BBVA Research. Working Paper No 13/29, 1-30.

Chang, H.-J. (2011). Institutions and Economic Development: Theory, Policy and History.

Doi:10.1017/S1744137410000378. Journal of Institutional Economics , 7 (4), 473-498.

Chege, L. M., \& Bichanga, J. (2017). Non-Performing Loans and Financial Performance of Banks: An Empirical Study of Commercial Banks in Kenya. International Journal of Management and Commerce Innovations , 4 (2), 909916.

Cichy, J., \& Szunke, A. (2013). Instruments to Guarantee the Financial Stability of the Banking Sector in the Long Term Towards their Assessment. 9th International Scientific Conference Financial Management of Firms and Financial Institutions (pp. 108-116). Ostrava, Czech Republic: VŠB-TU Ostrava, Faculty of Economics, Finance Department.

Čihák, M., Demirgüç-Kunt, A., Feyen, E., \& Levine, R. (2012, August 1). Benchmarking Financial Systems Around the World. World Bank Policy Research Working Paper No. 6175. Availble at SSRN: https://ssrn.com/abstract=2152254 , pp. 1-56.

Cull, R., Ehrbeck, T., \& Holle, N. (2014). "Financial Inclusion and Development: Recent Impact Evidence" Focus Note 92. Washington, D.C.: CGAP.

Desrochers, M., \& Lamberte, M. (2003, April). Efficiency and Expense Preference in Philippines' Cooperative Rural Banks. CIRPÉE, Centre Interuniversitaire de Recherche en Risque, Politique Economique et L'emploi, Faculté des Sciences de L'administration, Univeristé Laval, Québec, G1K 7P4, Canada. / PIDS, Philippines Institute of Development Studies. , pp. 1-27.

Fang, Y., Hasan, I., \& Marton, K. (2011). Bank Efficiency in Transition Economies: Recent Evidence from SouthEstern Europe. Bank of Finland Research. Discussion Papers , 1-43.

Finau, G., Rika, N., Samuwai, J., \& McGoon, J. (2016). Perceptions of Digital Financial Services in Rural Fiji. Information Technologies \& International Development [Special Issue] , 12 (4), 11-21.

Fiordelisi, F., Marques-Ibanez, D., \& Molyneux, P. (2010). Efficiency and Risk in European Banking. ECB European Central Bank. Working Paper Series No 1211, 1-39.

Hagendorff, J., Keasey, K., \& Vallascas, F. (2012, June 18). Systemic Size, Bank Risk and Systemic Crises. University of Edinburgh, 29 Buccleuch Place, Edinburgh EH8 9AL, UK/ University of Leeds, Maurice Keyworth Building, Leeds LS2 9JT, UK, pp. 1-48.

Hamid, N., Ramli, N. A., \& Sheikh Hussin, S. A. (2017). Efficiency Measurement of the Banking Sector in the Presence of Non-performing loan. AIP Conference Proceedings 1795, 020001 (2017); doi: 10.1063/1.4972145 (pp. 1-9). American Institute of Physics.

Hintošová, A. B., Demjanová, L., \& Lešková, L. (2013). Structural Analysis of Banking Sector in Slovakia. 9th International Scientific Conference Financial Management of Firms and Financial Institutions (pp. 248-255). Ostrava, Czech Republic: VŠB-TU Ostrava, Faculty of Economics, Finance Department.

Honohan, P., \& Beck, T. (2007). Making Finance Work for Africa. Washington DC 20433, USA: World Bank. Kablan, S. (2010). Banking Efficiency \& Financial Development in Sub-Saharan Africa. IMF Working Paper. WP/10/136. African Department , 1-26.

Kagoyire, A., \& Shukla, J. (2016). Effect of Credit Management on Performance of Commercial Banks in Rwanda (A Case Study of Equity Bank Rwanda LTD). International Journal of Business and Management Review , 4 (4), 1-12.

Kamberoglou, N. C., Liapis, E., Simigiannis, G. T., \& Tzamourani, P. (2004, January 9). Cost Efficiency in Greek Banking. Working Paper: Bank of Greece, Economic Research department and Statistics Department , pp. 1-33.

Kothari, C. R. (2004). Research Methodology (Methods and Techniques). New Delhi: New Age International (P) Ltd., Publishers.

Mehrotra, A., \& Yetman, J. (2015, March). Financial Inclusion - Issues for Central Banks. BIS Quarterly Review , pp. 83-96. 
Miklaszewska, E., Mikołajczyk, K., \& Pawłowska, M. (2014). Do Safe Banks Create Safe Systems? Central and Eastern European Banks' Perspective. Revue de l'OFCE , 243-267 https://www.cairn.info/revue-de-l-ofce-2014-1page-243.htm.

Mufandaedza, S. (2017). Determinants of Commercial Bank Lending Behaviour in Zimbabwe: An Empirical Investigation of the Post Dollarization Era. International Journal of Economics and Finance , 6 (3), 1-13.

Mutambanadzo, T., Bhiri, T., \& Makunike, S. (2013). An Analysis Challanges faced by Zimbabwean Micro Finance Institutions in Providing Financial Services to the Poor and Information Sector in the Dollarized Regime. Global Journal of Commerce and Management Perspective , 2 (3), 154-159.

Nikolaidoua, E., \& Vogiazas, S. (2017). Credit Risk Determinants in Sub-Saharan Banking Systems: Evidence from Five Countries and Lessons learnt from Central East and South East European Countries. Review of Development Finance, 52-63.

Niţoi, M., \& Spulbar, C. (2015). An Examination of Banks' Cost Efficiency in Central and Eastern Europe. 2nd International Conference 'Economic Scientific Research - Theoretical, Empirical and Practical Approaches', ESPERA 2014, 13-14 November 2014, Bucharest, Romania. 22, pp. 544-551. Bucharest: PROCEDIA Economics an Finance.

Nouaili, M., Abaoub, E., \& Ochi, A. (2015). The Determinants of Banking Performance in Front of Financial Changes: Case of Trade Banks in Tunisia. International Journal of Economics and Financial , 5 (2), 410-417.

Nyantakyi, E. B., \& Sy, M. (2015). The Banking System in Africa: Main Facts and Challenges. AFDB Africa Economic Brief, 6 (5), 1-16.

Obamuyi, T. M. (2013). Determinants of Banks' Profitability in A Developing Economy: Evidence from Nigeria. Organizations and Markets in Emerging Economies, 4 (2), 97-111.

Okungu, A. E., Mule, R. K., Nyongesa, D., Aila, F. O., Momanyi, G., Ogut, A. S., et al. (2014). Effect of Commercial Bank Loans on Financial Performance of Savings and Credit Co-operative Societies in Kisumu, Kenya. Greener Journal of Economics and Accountancy, 3 (1), 009-019.

Oso, Y. W., \& Onen, D. (2008). Guide to Research Writing Proposal and Report.

Rahim, R. A. (2016). Does Competition Foster Efficiency? Emperical Evidence from Malaysian Commercial Banks. Asian Academy of Management Journal of Accounting and Finance, 12 (1), 1-23.

Rivas, A., Ozuna, T., \& Policastro, F. (2006). Does the Use of Derivatives Increase Bank Efficiency? Evidence from Latin American Banks. International Business \& Economics Research Journal , 5 (11), 47-56.

Rosalinde, J. A., Woolthuis, K., \& Taminiau, Y. (2017, June). Waves of Change - The Dynamics of Institutional Pressures. Centre for Sustainable Entrepreneurship. University of Groningen/Campus Fryslân , pp. 3-44.

Said, R. M., Nor, F. M., Low, S.-W., \& Abdul Rahman, A. (2008). The Efficiency Effects of Mergers and Acquisitions in Malaysian Banking Institutions. Asian Journal of Business and Accounting , 1 (1), 47-66.

Saqib, N. (2013). Impact of Development \& Efficiency of Financial Sector on Economic Growth: Empirical Evidence from Developing Countries. Journal of Knowledge Management, Economics and Information Technology, III (3), 115.

Saunders, M., Lewis, P., \& Thornhill, A. (2009). Research Methods for Business Students. Harlow: Pearson Education Limited.

Siudek, T. (2008). Theoretical Foundations of Banks Efficiency and Emperical Evidence from Poland. Socialiniai tyrimai / Social Research, 3 (13), 150-158.

Spulbăr, C., Niţoi, M., \& Angel, L. (2015). Efficiency in Cooperative Banks and Savings Banks: A Stochastic Frontier Approach. Romanian Journal of Economic Forecasting , XVIII (1), 5-21.

Stiansen, E., \& Guyer, J. I. (1999). Credit, Currencies and Culture (African Financial Institutions in Historical Perspective). Stockholm: Nordiska Afrikainstitutet (The Nordic Africa Institute).

Suddaby, R. (2013). Institutional Theory. In E. H. Kessler, Encyclopedia of Management Theory (pp. 379-383). Los Angeles; London; New Delhi; Singapore; Washington DC: Janke, Rolf, A. (SAGE Publications).

Tayie, S. (2005). Research Methods and Writing Research Proposals. Cairo: Centre for Advancement of Post Graduate Studies and Research in Engineering Sciences, Faculty of Engineering-Cairo University (CAPSCU).

Trochim, W. K., \& Donnelly, J. P. (2007). The Research Methods Knowledge Base. United States of America: Thomson. 
Ugoani, J. N. (2015). Poor Credit Risk Management and Bank Failures in Nigeria. International Journal of Economics and Business Administration , 1 (1), 17-24.

UNCTAD. (2014, September 3). Impact of Access to Financial Services, Including by Highlighting Remittances on Development: Economic Empowerment of Women and Youth. United Nations Conference on Trade and Development, pp. 1-20.

Uzokwe, N. J., \& Ohaeri, C. S. (2014). Distress in the Nigerian Banking Industry - Causes, Effects and Strategies for Solution. International Journal of Science and Research (IJSR) , 3 (10), 76-81.

Wang, F., Yang, S., Reisner, A., \& Liu, N. (2019). Does Green Credit Policy Work in China? The Correlation between Green Credit and Corporate Environmental Information Disclosure Quality. Sustainability, 1-15.

Wang, Z. Y., \& Zhong, X. (2017). The Study on Influence Period of the Green Credit Policy Based on CGE Model. Advances in Social Science, Education and Humanities Research. 4th International Conference on Education, Management and Computing Technology (ICEMCT 2017) (pp. 1-5). Guangdong, Guangzhou, China 510000: Institute of finance, Guangzhou University.

Weber, O. (2016, March 21). The Sustainability Performance of Chinese Banks: Institutional Impact. School for Environment, Enterprise and Development (University of Waterloo) , pp. 1-29.

Wu, X. J., \& Zhang, X. H. (2018). Analysis of the Problems and Countermeasures of China's Green Credit. Journal of Geoscience and Environment Protection , 111-119 https://doi.org/10.4236/gep.2018.66009.

Zago, A., \& Dongili, P. (2006, November). Bad Loans and Efficiency in Italian Banks. Dipartimento di Scienze Economiche - Università di Verona , pp. 1-51. 